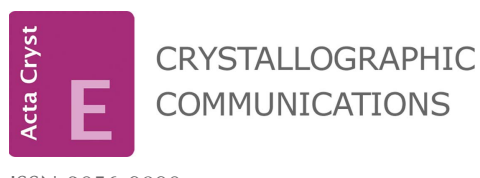

ISSN 2056-9890

Received 29 October 2018

Accepted 31 October 2018

Edited by W. T. A. Harrison, University of Aberdeen, Scotland

Keywords: crystal structure; thioether; phosphane oxide; hydrogen bonding; Hirshfeld surface analysis.

CCDC reference: 1876525

Supporting information: this article has supporting information at journals.iucr.org/e

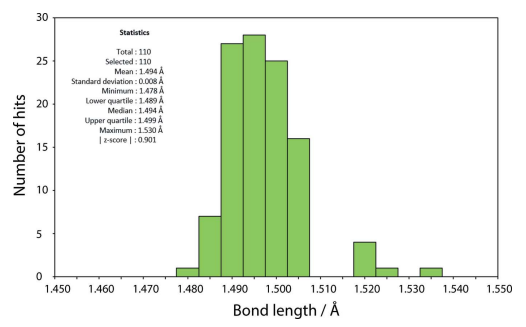

OPEN $\odot$ ACCESS

\section{A 1:2 co-crystal of 2,2'-thiodibenzoic acid and triphenylphosphane oxide: crystal structure, Hirshfeld surface analysis and computational study}

\author{
Sang Loon Tan* and Edward R. T. Tiekink*
}

Research Centre for Crystalline Materials, School of Science and Technology, Sunway University, 47500 Bandar Sunway, Selangor Darul Ehsan, Malaysia. *Correspondence e-mail: alant@sunway.edu.my, edwardt@sunway.edu.my

The asymmetric unit of the title co-crystal, 2,2'-thiodibenzoic acid-triphenylphosphane oxide $(1 / 2), \mathrm{C}_{14} \mathrm{H}_{10} \mathrm{O}_{4} \mathrm{~S} \cdot 2 \mathrm{C}_{18} \mathrm{H}_{15} \mathrm{OP}$, comprises two molecules of 2,2'-thiodibenzoic acid [TDBA; systematic name: 2-[(2-carboxyphenyl)sulfanyl]benzoic acid] and four molecules of triphenylphosphane oxide [TPPO; systematic name: (diphenylphosphoryl)benzene]. The two TDBA molecules are twisted about their disulfide bonds and exhibit dihedral angles of 74.40 (5) and $72.58(5)^{\circ}$ between the planes through the two $\mathrm{SC}_{6} \mathrm{H}_{4}$ residues. The carboxylic acid groups are tilted out of the planes of the rings to which they are attached forming a range of $\mathrm{CO}_{2} / \mathrm{C}_{6}$ dihedral angles of $19.87(6)-60.43(8)^{\circ}$. Minor conformational changes are exhibited in the TPPO molecules with the range of dihedral angles between phenyl rings being $-2.1(1)$ to $-62.8(1)^{\circ}$. In the molecular packing, each TDBA acid molecule bridges two TPPO molecules via hydroxy-O $-\mathrm{H}$...O(oxide) hydrogen bonds to form two three-molecule aggregates. These are connected into a three-dimensional architecture by TPPO-C $-\mathrm{H} \cdots \mathrm{O}$ (oxide, carbonyl) and TDBA-C $-\mathrm{H} \cdots$ (oxide, carbonyl) interactions. The importance of $\mathrm{H} \cdots \mathrm{H}, \mathrm{O} \cdots \mathrm{H} / \mathrm{H} \cdots \mathrm{O}$ and $\mathrm{C} \cdots \mathrm{H} / \mathrm{H} \cdots \mathrm{C}$ contacts to the calculated Hirshfeld surfaces has been demonstrated. In terms of individual molecules, $\mathrm{O} \cdots \mathrm{H} / \mathrm{H} \cdots \mathrm{O}$ contacts are more important for the TDBA ( $c$ a 28\%) than for the TPPO molecules ( $c a$ 13\%), as expected from the chemical composition of these species. Computational chemistry indicates the four independent hydroxy-O $-\mathrm{H} \cdots \mathrm{O}$ (oxide) hydrogen bonds in the crystal impart about the same energy ( $c a 52 \mathrm{~kJ} \mathrm{~mol}^{-1}$ ), with DTBA-phenyl-C-H..OO(oxide) interactions being next most stabilizing $\left(c a 40 \mathrm{~kJ} \mathrm{~mol}^{-1}\right)$.

\section{Chemical context}

2-Thiosalicylic acid, also known as 2-mercaptobenzoic acid, being an analogue to salicylic acid, has many applications. In medicine, is dianion is found in the salt $\mathrm{Na}\left[\mathrm{EtHg}\left(\mathrm{SC}_{6} \mathrm{H}_{4} \mathrm{CO}_{2}\right)\right]$, which displays anti-fungal and anti-septic activities (Bigham \& Copes, 2005). Other uses include as anti-corrosion agents (Chien et al., 2012), as reactive agents or modifiers for nanoparticles and electrochemical sensing (Cang et al., 2017; Sikarwar et al., 2014), as catalysts for organic syntheses (Yang et al., 2018; Selig \& Miller, 2011) as well as being the precursor for some anti-viral and anti-microbial agents (Saha et al., 2017). The compound readily coordinates a wide variety of metals, in both neutral and anionic form, due to the presence of both hard (oxygen) and soft (sulfur) donor atoms and exhibits different modes of coordination. Very recent reviews of the coordination chemistry of 2-thiosalicylic acid (WehrCandler \& Henderson, 2016) and the isomeric 3- and 4-species (Tiekink \& Henderson, 2017) are available. However, a restriction in the chemistry of this molecule is found as it can 
undergo various $\mathrm{pH}$-dependent transformations, i.e. it remains intact in acidic condition but may be oxidized to form 2,2'dithiodibenzoic acid at neutral $\mathrm{pH}$. For example and relevant to the present contribution, are studies of co-crystal formation between 2-thiosalicylic acid and bipyridyl-type molecules (Broker \& Tiekink, 2007) whereby 2-thiosalicylic acid was oxidized to 2,2'-dithiodibenzoic acid during co-crystallization. During attempts to react 2-thiosalicylic acid with copper(I) chloride in the presence of two equivalents of triphenylphosphane, motivated by the desire to prepare analogues of phosphanecopper(I) dithiocarbamate derivatives which exhibit promising anti-bacterial activity (Jamaludin et al., 2016), the title co-crystal was isolated, i.e. the $1: 2$ co-crystal of $2,2^{\prime}$-thiodibenzoic acid and triphenylphosphane oxide (I). Unexpectedly, both organic reagents were found to have oxidized in the presence of copper(I) chloride in acetonitrile solution under neutral conditions. While the actual mechanism remains unclear, a very recent study describes related synthetic outcomes (Gorobet et al., 2018). Herein, the crystal and molecular structures, the analysis of the calculated Hirshfeld surface and calculation of the interaction energies through a computational approach for (I) are described.<smiles>O=C(O)c1ccccc1Sc1ccccc1C(=O)O</smiles><smiles>O=P(c1ccccc1)(c1ccccc1)c1ccccc1</smiles>

\section{Structural commentary}

$\mathrm{X}$-ray crystallography reveals the title co-crystal to comprise $2,2^{\prime}$-thiodibenzoic acid (TDBA) and triphenylphosphane oxide (TPPO) in the ratio 1:2, but with two independent TDBA molecules, Fig. 1, and four independent TPPO molecules, Fig. 2, in the asymmetric unit.

Each TDBA molecule comprises two benzoic acid residues connected in the 2-positions by a sulfur bridge. The confirmation of the presence of carboxylic acid groups is readily seen in the disparity in the $\mathrm{C}-\mathrm{O}$ (hydroxy) and $\mathrm{C}=\mathrm{O}$ (carbonyl) bond lengths with the minimum difference seen for the $\mathrm{C} 100=\mathrm{O} 11$ and $\mathrm{C} 100-\mathrm{O} 12$ bonds of 1.3126 (15) and 1.2075 (16) A, respectively. As expected, the thiophenyl residues are almost planar with the maximum r.m.s. deviation of $0.053 \AA$ being found for the S1,C80-C85 atoms. The thiophenyl rings are deviated from the perfect perpendicular bisector with dihedral angles of $74.40(5)$ and $72.58(5)^{\circ}$ for the S1- and S2-molecules, respectively. Finally, the O6-, O8-, O10and O12- carboxylic acid groups are tilted from the phenyl rings they are connected to by 60.43 (8), 24.24 (7), 19.87 (6) and $45.78(7)^{\circ}$, respectively. That there are no major conformational differences between the molecules is evidenced from the overlay diagram of Fig. 3 (r.m.s. deviation $=0.118 \AA$ ). (a)

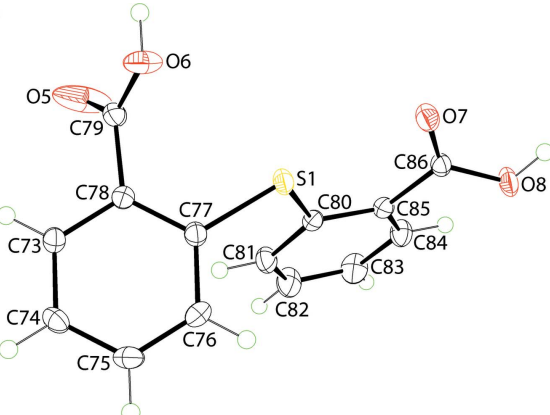

(b)

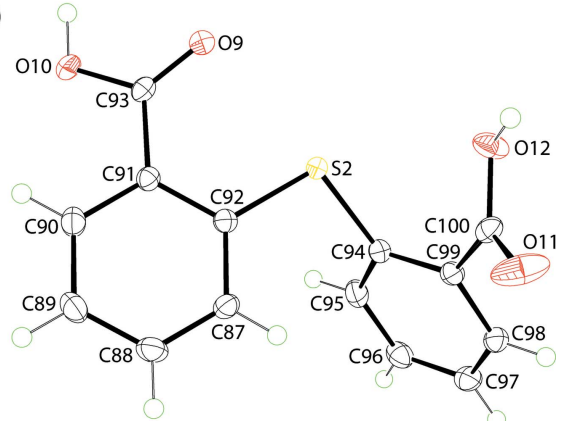

Figure 1

The molecular structures of the two independent molecules of $2,2^{\prime}$ thiodibenzoic acid in the asymmetric unit of (I), showing the atomlabelling scheme and displacement ellipsoids at the $70 \%$ probability level.

The molecular structures of the TPPO coformers are more rigid. This is seen in the $\mathrm{O}-\mathrm{P}-\mathrm{C}-\mathrm{C}$ torsion angles, which range from 17.7 (1) to $61.6(1), 19.8$ (1) to $61.5(1),-2.1$ (1) to $-62.8(1)$ and $-19.2(1)$ to $-44.5(1)^{\circ}$ for the P1-P4-molecules, respectively. In the same way, the $\mathrm{P}=\mathrm{O}$ bond lengths span an experimentally equivalent range, i.e. $1.4975(8)$

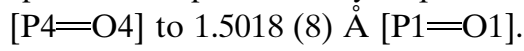

(a)

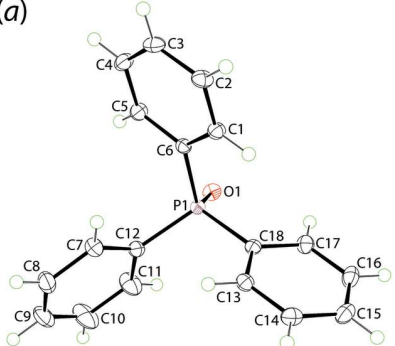

(c)

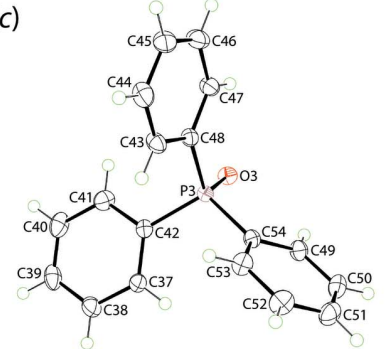

(b)

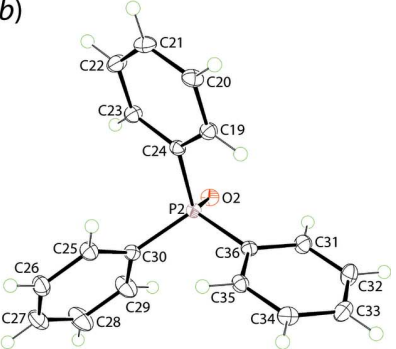

(d)

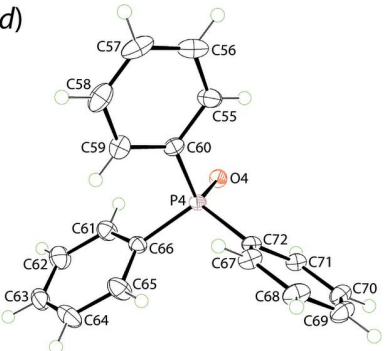

Figure 2

The molecular structures of the four independent molecules of triphenylphosphane oxide in the asymmetric unit of (I), showing the atom-labelling scheme and displacement ellipsoids at the $70 \%$ probability level. 


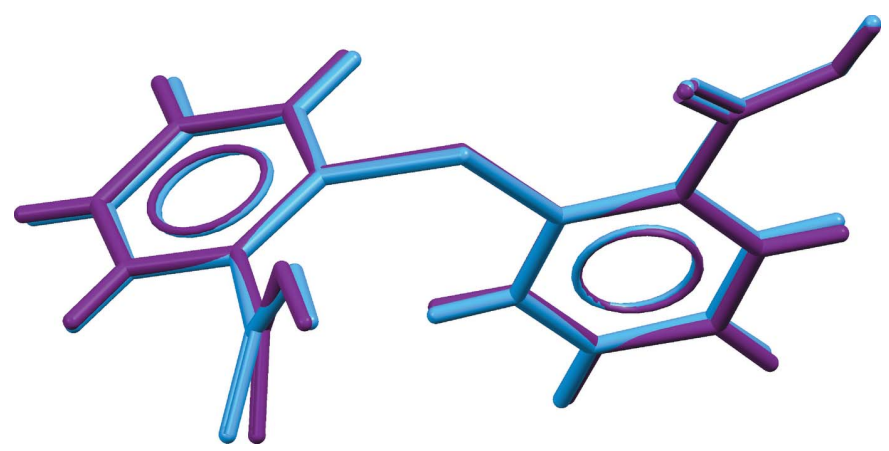

Figure 3

An overlay diagram of the two independent molecules of $2,2^{\prime}$-thiodibenzoic, with S1-molecule (purple) and S2-molecule (light-blue) superimposed so that a pair thiophenyl moieties are coincident.

\section{Supramolecular features}

Geometric parameters characterizing the identified (PLATON; Spek, 2009) interatomic contacts in the crystal of (I) are given in Table 1. The most prominent feature of the molecular packing is the formation of hydroxy-O$\mathrm{H}$... O(oxide) hydrogen bonds. These occur so that each molecule of 2,2'-thiodibenzoic acid (TDBA) links two triphenylphosphane oxide (TPPO) molecules to form a pair of three-molecule aggregates with a 13-membered, linear $\left\{\mathrm{O} \cdots \mathrm{HOC}_{3} \mathrm{SC}_{3} \mathrm{OH} \cdots \mathrm{O}\right\}$ heterosynthon as illustrated in Fig. 4. These aggregates are connected into a three-dimensional architecture by a large number of $\mathrm{C}-\mathrm{H} \cdots \mathrm{O}$ interactions. Two

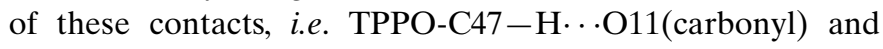

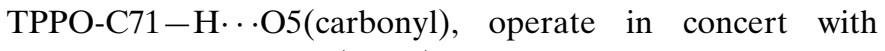

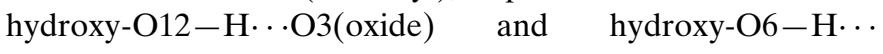
$\mathrm{O} 4$ (oxide) hydrogen bonds, respectively, to close a ninemembered $\left\{\mathrm{HC}_{2} \mathrm{PO} \cdots \mathrm{HOCO} \cdots\right\}$ synthon. The $\mathrm{C}-\mathrm{H} \cdots \mathrm{O}$ contacts are of the type TPPO-C $-\mathrm{H} \cdots \mathrm{O}$ (oxide, carbonyl)

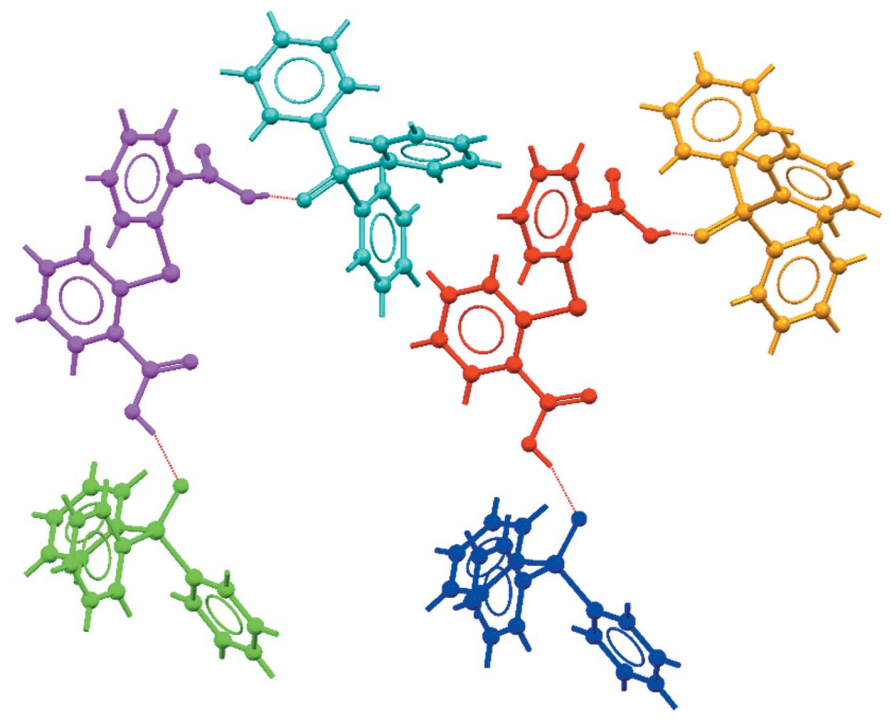

Figure 4

The two three-molecule aggregates in the crystal of (I). The hydroxy-O$\mathrm{H}$.. O (oxide) hydrogen bonds are shown as red dashed lines. Colour code: S1-containing molecule, purple; S2, red; P1, green; P2, blue; P3, yellow; P4, light-blue.
Table 1

Hydrogen-bond geometry $\left(\AA{ }^{\circ}\right)$.

\begin{tabular}{|c|c|c|c|c|}
\hline$D-\mathrm{H} \cdots A$ & $D-\mathrm{H}$ & $\mathrm{H} \cdots A$ & $D \cdots A$ & $D-\mathrm{H} \cdots A$ \\
\hline $\mathrm{O} 6-\mathrm{H} 6 \mathrm{O} \cdots \mathrm{O} 4$ & $0.95(2)$ & $1.66(2)$ & $2.6070(12)$ & $171(2)$ \\
\hline $\mathrm{O} 8-\mathrm{H} 80 \cdots \mathrm{O} 1^{\mathrm{i}}$ & $0.90(2)$ & $1.70(2)$ & $2.5763(12)$ & $163(2)$ \\
\hline $\mathrm{O} 10-\mathrm{H} 10 O \cdots \mathrm{O} 2^{\mathrm{ii}}$ & $0.91(2)$ & $1.72(2)$ & $2.6077(12)$ & $163(2)$ \\
\hline $\mathrm{O} 12-\mathrm{H} 12 O \cdots \mathrm{O} 3^{\mathrm{iii}}$ & $0.90(2)$ & $1.71(2)$ & $2.5978(12)$ & $170.9(19)$ \\
\hline $\mathrm{C} 16-\mathrm{H} 16 \cdots \mathrm{O} 4$ & 0.93 & 2.53 & $3.3333(15)$ & 144 \\
\hline $\mathrm{C} 44-\mathrm{H} 44 \cdots \mathrm{O} 4^{\mathrm{iv}}$ & 0.93 & 2.43 & 3.2404 (17) & 145 \\
\hline $\mathrm{C} 52-\mathrm{H} 52 \cdots \mathrm{O} 11^{\mathrm{v}}$ & 0.93 & 2.49 & $3.3231(16)$ & 149 \\
\hline $\mathrm{C} 62-\mathrm{H} 62 \cdots \mathrm{O} 11^{\mathrm{i}}$ & 0.93 & 2.51 & $3.367(2)$ & 153 \\
\hline $\mathrm{C} 64-\mathrm{H} 64 \cdots \mathrm{O}^{\mathrm{vi}}$ & 0.93 & 2.46 & $3.263(2)$ & 144 \\
\hline $\mathrm{C} 68-\mathrm{H} 68 \cdots \mathrm{O}^{\mathrm{vi}}$ & 0.93 & 2.55 & $3.2747(17)$ & 135 \\
\hline $\mathrm{C} 71-\mathrm{H} 71 \cdots \mathrm{O} 5$ & 0.93 & 2.59 & $3.2765(18)$ & 131 \\
\hline $\mathrm{C} 75-\mathrm{H} 75 \cdots \mathrm{O} 2^{\mathrm{i}}$ & 0.93 & 2.41 & $3.1184(16)$ & 133 \\
\hline $\mathrm{C} 96-\mathrm{H} 96 \cdots \mathrm{O} 1$ & 0.93 & 2.49 & $3.1832(15)$ & 132 \\
\hline
\end{tabular}

Symmetry codes: (i) $x+1, y, z$; (ii) $x+1, y, z+1$; (iii) $x, y, z+1 ; \quad$ (iv) $x-1,-y+\frac{1}{2}, z-\frac{3}{2}$; (v) $x,-y+\frac{1}{2}, z-\frac{3}{2}$; (vi) $x,-y+\frac{1}{2}, z-\frac{1}{2}$.

and TDBA-C $-\mathrm{H} \cdots \mathrm{O}$ (oxide, carbonyl), Table 1. In addition to participating in hydroxy-O $-\mathrm{H} \cdots \mathrm{O}$ (oxide) hydrogen bonds, each of the O1-O3 atoms of TPPO form an additional $\mathrm{C}-\mathrm{H} \cdots \mathrm{O}$ (oxide) contact whereas the $\mathrm{O} 4$ atom participates in two such interactions. One carbonyl group of each TDBA molecule, i.e. the $\mathrm{O} 5$ and $\mathrm{O} 11$ atoms, participates in two $\mathrm{C}-$ $\mathrm{H} \cdots \mathrm{O}$ (carbonyl) interactions, leaving no formal role for the carbonyl-O7 and $\mathrm{O} 9$ atoms in the molecular packing. A view of the unit-cell contents is shown in Fig. 5.

In terms of distinguishing between molecules based on intermolecular contacts, the carbonyl-O5 atom of DTBA accepts $\mathrm{C}-\mathrm{H} \cdots \mathrm{O}$ interactions from phenyl rings derived from TPPO and DTBA, whereas the carbonyl-O11 atom accepts contacts from TPPO only. The DPPO-O4 atom is distinct from the $\mathrm{O} 1-\mathrm{O} 3$ atoms based on the number of interactions it forms. In common with the $\mathrm{O} 4$ atom, $\mathrm{O} 3$ accepts a $\mathrm{C}-\mathrm{H} \cdots \mathrm{O}$ interaction from TPPO, whereas each of the O1 and $\mathrm{O} 2$ participates in DTBA-C $-\mathrm{H} \cdots \mathrm{O}$ contacts.

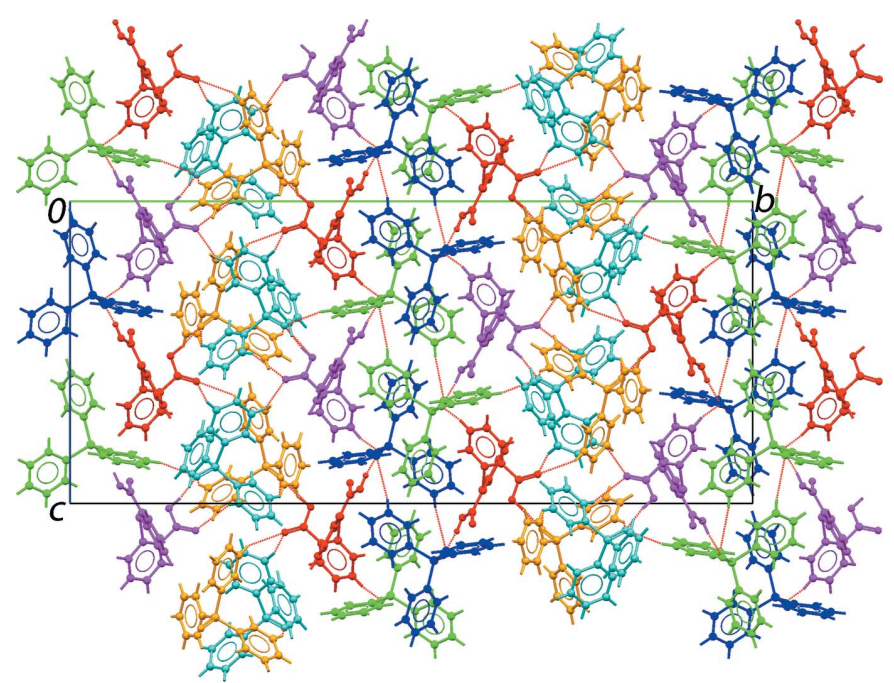

Figure 5

A view of the unit-cell contents shown in projection down the $a$ axis. The molecules are colour-coded as for Fig. 4. 
Table 2

Summary of short C $\cdots H$ interatomic contacts $(\AA)$ in $(I)$.

\begin{tabular}{lll}
\hline Contact & Separation & Symmetry operation \\
\hline $\mathrm{C} 13 \cdots \mathrm{H} 10$ & 2.80 & $1-x, 1-y, 1-z$ \\
$\mathrm{C} 14 \cdots \mathrm{H} 10$ & 2.84 & $1-x, 1-y, 1-z$ \\
$\mathrm{C} 35 \cdots \mathrm{H} 28$ & 2.77 & $-x, 1-y,-z$ \\
$\mathrm{C} 34 \cdots \mathrm{H} 28$ & 2.94 & $-x, 1-y,-z$ \\
\hline
\end{tabular}

\section{Hirshfeld surface analysis}

The independent 2,2'-thiodibenzoic acid (TDBA) and triphenylphosphane oxide (TPPO) molecules of (I) were subjected to Hirshfeld surface analysis following a literature precedent on a multi-component crystal (Jotani et al., 2018) to further understand the nature of the intermolecular interactions in the crystal. As shown in Fig. 6(a)- $(f)$, the pair of TDBA-S1 and -S2 molecules, shown with the respective pairs of hydrogen bonded TPPO molecules, as well as the TPPO$\mathrm{P} 1-\mathrm{P} 4$ molecules exhibit some similarities especially on the prominent close contacts as represented by the intense red regions on the corresponding $d_{\text {norm }}$ surface mappings, which are mainly dominated by hydroxy- $\mathrm{O}-\mathrm{H} \cdots \mathrm{O}$ (oxide) interactions.

Upon close inspection on the surface mapping, minor differences are observed between the pair of TDBA molecules. Specifically, a diminutive red spot is observed near one of the terminal carboxylic groups of the S1-molecule arising from a TPPO-phenyl-C-H $-\mathrm{OO}$ (carbonyl) interaction but, no such contact is apparent for the S2-molecule. As for the two pairs of TPPO molecules, the significant difference between the TPPO-P1 and -P4 molecules, linked to S1-DTBA, and the TPPO-P2 and P3 molecules, linked to the S2-TDBA, is the (a)

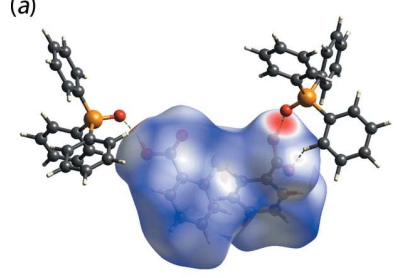

(d)

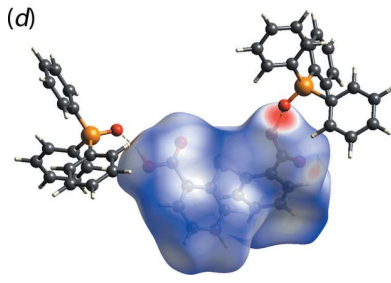

(b)

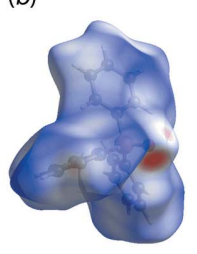

(e)

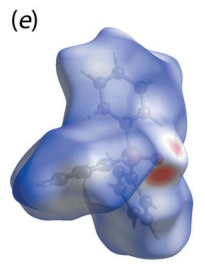

(c)

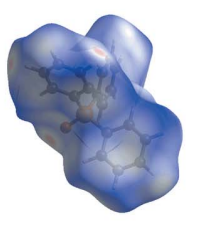

$(f)$

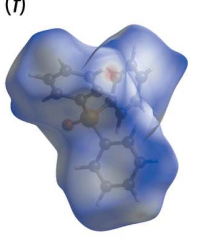

Figure 6

Views of the Hirshfeld surfaces mapped over $d_{\text {norm }}$ for components of (I) for the: (a) S1-DTBA molecule hydrogen bonded (red dashed lines) to the P1- (left) and P4-TPPO molecules, (b) P1-TPPO, (c) P4-TPPO, (d) S2DTBA molecule hydrogen bonded to the P2- (left) and P3-TPPO molecules, (e) P2-TPPO and ( $f$ ) P3-TPPO. The surfaces in $(a)-(c)$ are mapped over the range -0.766 to 1.446 a.u., and those in $(d)-(f)$ over the range -0.766 to 1.563 a.u.
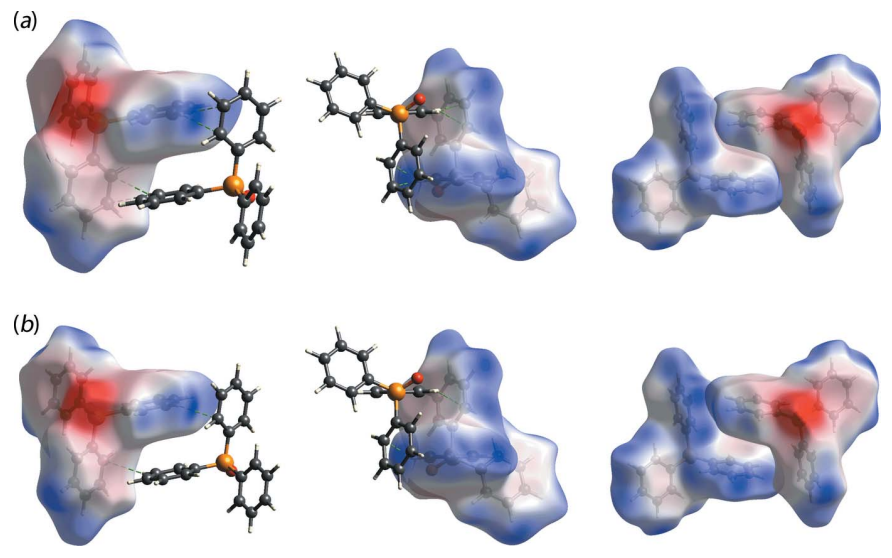

Figure 7

Different views of the Hirshfeld surfaces mapped over electrostatic potential for the centrosymmetrically related molecules of TPPO interacting via semi-localized phenyl-C $-\mathrm{H} \cdots \pi$ (phenyl) interactions: (a) P1-TPPO, in the range of -0.100 to 0.041 a.u. and (b) P2-TPPO molecules ( -0.100 to 0.041 a.u.).

presence of additional red spots on the surface mapping of the phenyl rings for P1- and P2-molecules in contrast to their P3and P4-containing counterparts. This difference may be attributed to the complementary phenyl- $\mathrm{C}-\mathrm{H} \cdots \pi$ (phenyl) interactions between centrosymmetrically-related molecules, as illustrated in Fig. 7 and tabulated in Table 2. Here, the interacting $\mathrm{H} 10$ and $\mathrm{H} 28$ atoms are directed towards two carbon atoms of a symmetry-related ring so that the interactions are best described as being semi-localized as opposed to delocalized, which corresponds to the situation where the interacting hydrogen atom is equally separated from all six carbon atoms of the ring (Schollmeyer et al., 2008).

Quantitative evaluation of the Hirshfeld surfaces by the combination of the $d_{\mathrm{i}}$ and $d_{\mathrm{e}}(i$ is internal and $e$ is external to the surface) contact distances in intervals of $0.01 \AA$ gives the overall two-dimensional fingerprint plots for the entire asymmetric unit of (I), Fig. 8(a), and each of the individual TDBA, Fig. 9(a), and TPPO, Fig. 10(a), molecules. Further, these can be delineated into specific contacts (McKinnon et al., 2007) and Figs. 9-10(b)-(d) give fingerprint plots delineated into $\mathrm{H} \cdots \mathrm{H}, \mathrm{O} \cdots \mathrm{H} / \mathrm{H} \cdots \mathrm{O}$ and $\mathrm{C} \cdots \mathrm{H} / \mathrm{H} \cdots \mathrm{C}$ contacts. The relative contributions of these contacts to the surfaces is given in Table 3.

The overall fingerprint plot for (I), Fig. $8 a$, is quite different for the individual components, Figs. 9-10a, as the former is a sum of all the individual surface contacts, which differ for the individual molecules. As expected, the same is true for the corresponding decomposed fingerprint plots. The major contribution to the overall surface of (I), i.e. 49.4\%, comes from $\mathrm{H} \cdots \mathrm{H}$ contacts. The $\mathrm{O} \cdots \mathrm{H} / \mathrm{H} \cdots \mathrm{O}$ contacts $\left(d_{\mathrm{e}}+d_{\mathrm{i}} \sim\right.$ $2.34 \AA$ ) make a significant contribution at $13.7 \%$, while the C. . H $/ \mathrm{H} \cdots \mathrm{C}$ interactions $\left(d_{\mathrm{e}}+d_{\mathrm{i}} \sim 2.66 \AA\right)$, at $30.1 \%$, play a more prominent role.

The formation of the 13-membered $\left\{\mathrm{O} \cdots \mathrm{HOC}_{3} \mathrm{SC}_{3} \mathrm{OH} \cdots \mathrm{O}\right\}$ heterosynthon, Fig. 4, is clearly reflected in the corresponding full fingerprint plots of the individual molecules Figs. 9-10(a), which exhibit an almost 
Table 3

Percentage contributions of interatomic contacts to the Hirshfeld surface for (I) and for the the individual TDBA and DPPO molecules.

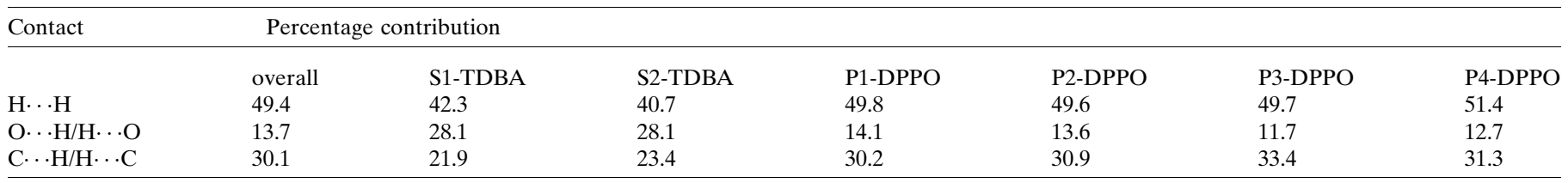

identical claw-like fingerprint profile but arranged in the exact reverse order, i.e. Fig. 9(a) cf. Fig. 10(a). Among all the close interactions, $\mathrm{H} \cdots \mathrm{H}$ contacts, Figs. 8-9b, represent the dominant interactions to the individual surfaces, i.e. $41-42 \%$ for the TDBA molecules and $49-51 \%$ for the DPPO molecules, and exhibit $d_{\mathrm{e}}+d_{\mathrm{i}}$ contact distances ranging from 2.24 to $2.38 \AA$ which is very close to the sum of van der Waals radii of $2.4 \AA$.

The $\mathrm{O} \cdots \mathrm{H}$ hydrogen bonds constitute the strongest among all interactions present in the co-crystal and lead to formation of asymmetric, forceps-like profiles in the corresponding decomposed fingerprint plots, Figs. 9-10(c). These feature two tips - one at relatively short $d_{\mathrm{e}}+d_{\mathrm{i}} \sim 1.6 \AA$ that can be attributed to the hydroxy-H. . O (oxide) hydrogen bonds for the S1- and S2-TDBA molecules, Fig. 10(c), or oxide$\mathrm{O} \cdot \mathrm{H}$ (hydroxy) hydrogen bonds for P1-P4-TPPO. The other tip has a relatively long $d_{\mathrm{e}}+d_{\mathrm{i}}$ value of $\sim 2.4 \AA$ and arises as a result of hydroxy-O $\cdots \mathrm{H}$ (phenyl) contacts for S1- and S2TDBA or phenyl-H...O(hydroxy) for P1-P4-TPPO. The $\mathrm{O} \cdots \mathrm{H} / \mathrm{H} \cdots \mathrm{O}$ contacts constitute the second most dominant interactions for the TDBA molecules and third most for the TPPO molecules, Table 3.

Similar to the $\mathrm{H} \cdots \mathrm{H}$ contacts, the $\mathrm{C} \cdots \mathrm{H} / \mathrm{H} \cdots \mathrm{C}$ interactions contribute weakly to the molecular packing of the cocrystal as evidenced from the $d_{\mathrm{e}}+d_{\mathrm{i}}$ distance range of 2.7$2.8 \AA$, i.e. close to the sum of van der Waals radii of $2.9 \AA$, despite the contacts constituting the third most dominant interaction in the TDBA molecules ( $c$ a 22\%) and being the second most dominant for the TPPO molecules ( $c$ a 32\%). An exception to the trend is found for the P1- and P2-TPPO molecules, which display relatively short contact distances at ca $2.6 \AA$ owing to the formation of $\mathrm{C}-\mathrm{H} \cdots \pi$ interactions as discussed above. (a)

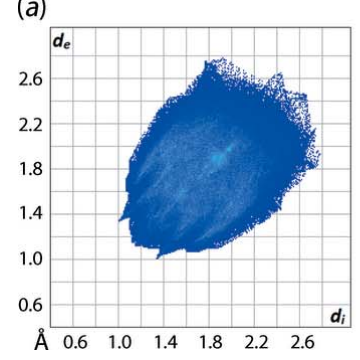

(b)

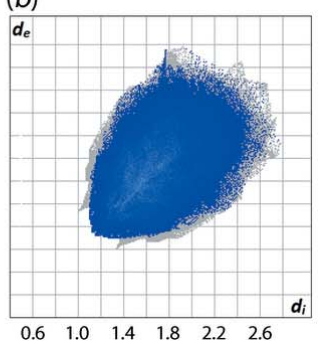

(c)

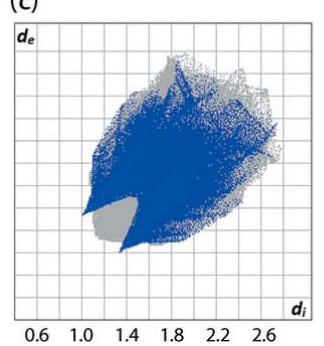

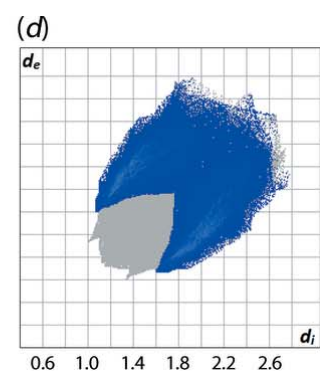

Figure 8

(a) The full two-dimensional fingerprint plot for $(\mathrm{I})$ and $(b)-(d)$ those delineated into $\mathrm{H} \cdots \mathrm{H}, \mathrm{O} \cdots \mathrm{H} / \mathrm{H} \cdots \mathrm{O}$ and $\mathrm{C} \cdots \mathrm{H} / \mathrm{H} \cdots \mathrm{C}$ contacts, respectively.
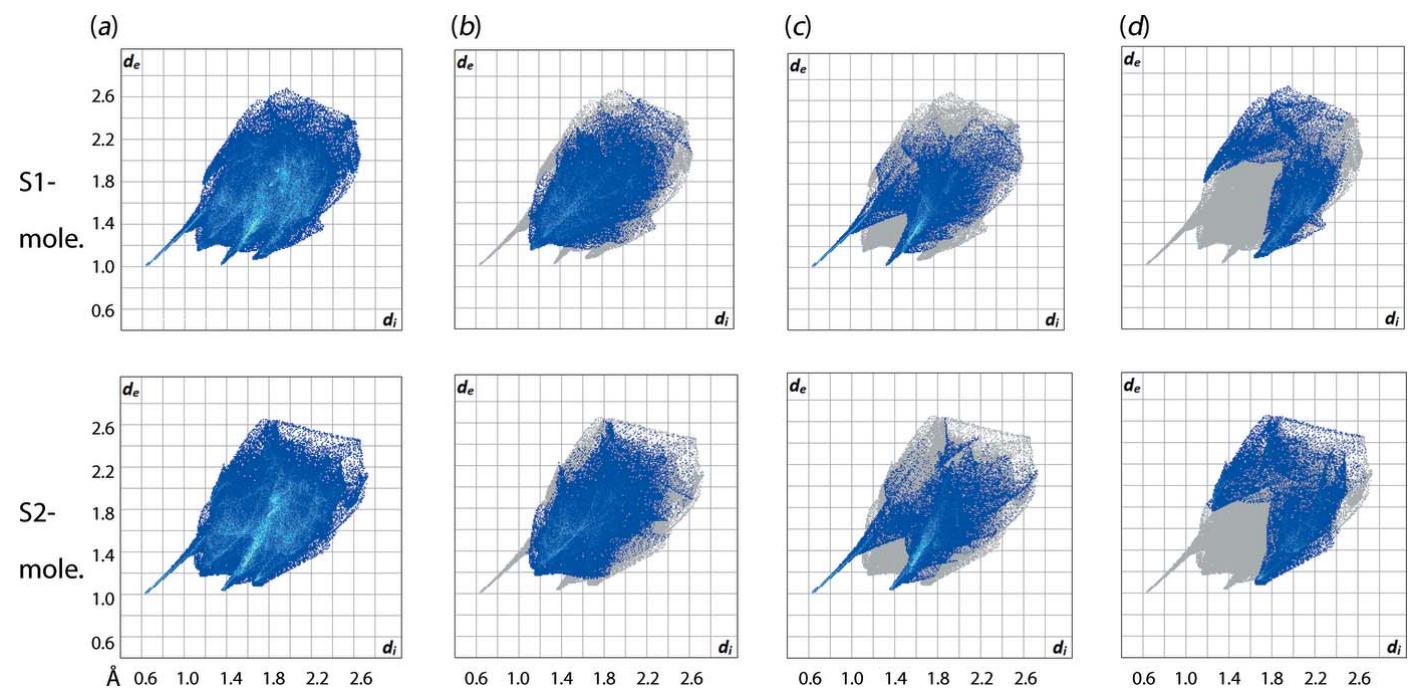

Figure 9

(a) The full two-dimensional fingerprint plot for the two independent TDBA molecules in (I) and $(b)-(d)$ those delineated into $\mathrm{H} \cdots \mathrm{H}, \mathrm{O} \cdots \mathrm{H} / \mathrm{H} \cdots \mathrm{O}$ and $\mathrm{C} \cdots \mathrm{H} / \mathrm{H} \cdots \mathrm{C}$ contacts, respectively. 
(a)
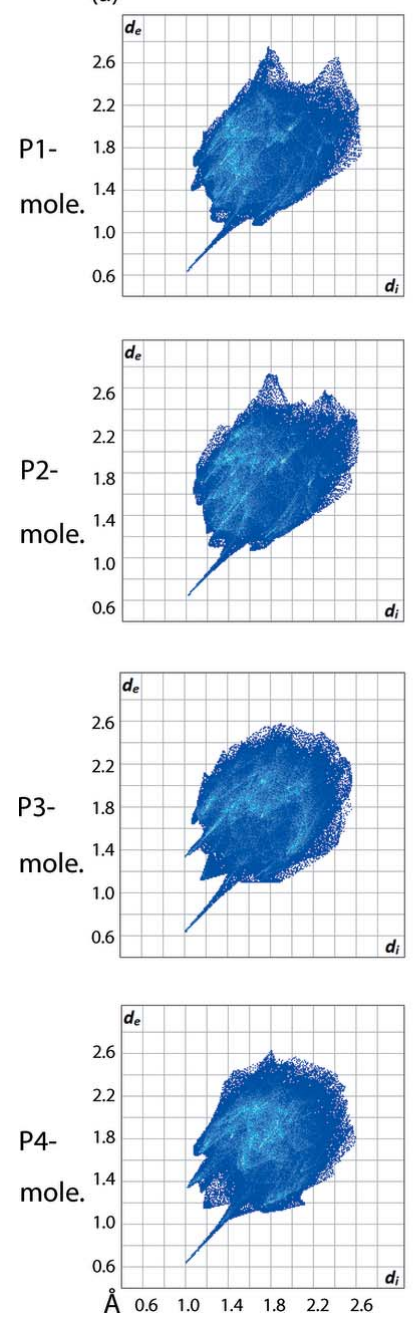

(b)
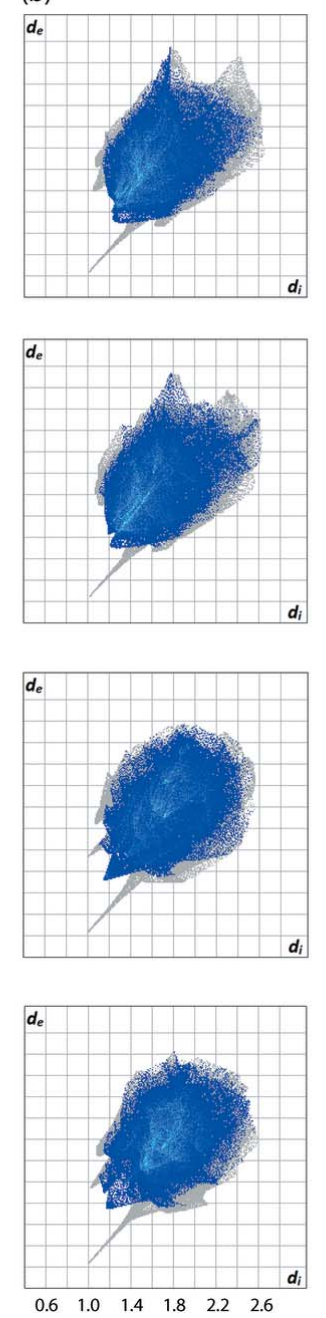

(c)
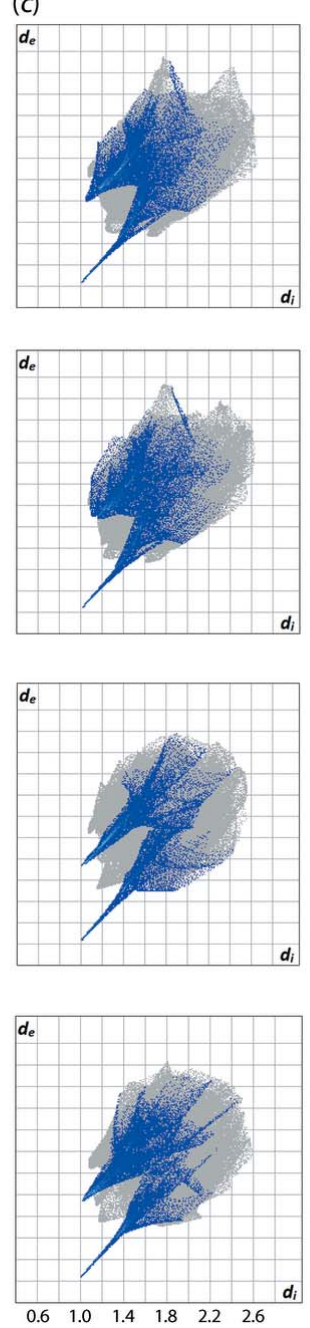
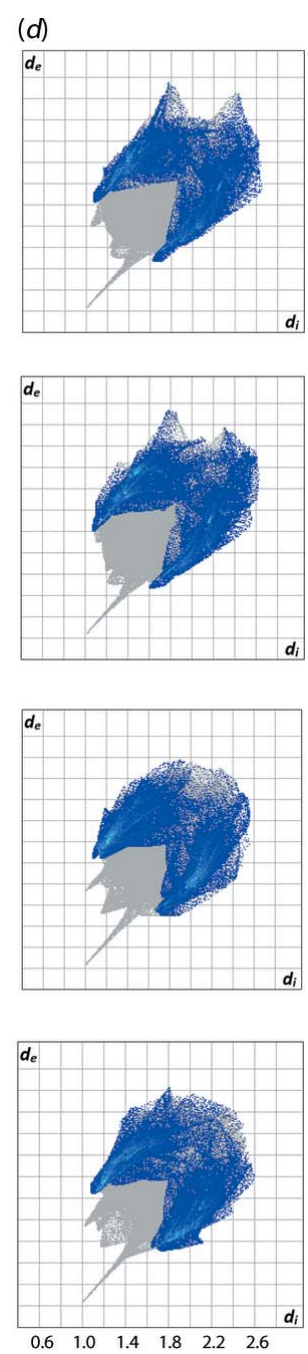

Figure 10

(a) The full two-dimensional fingerprint plot for the four independent TPPO molecules in (I) and (b)-(d) those delineated into $\mathrm{H} \cdots \mathrm{H}, \mathrm{O} \cdots \mathrm{H} / \mathrm{H} \cdots \mathrm{O}$ and $\mathrm{C} \cdots \mathrm{H} / \mathrm{H} \cdots \mathrm{C}$ contacts, respectively.

In summary the Hirshfeld surface analysis on (I), with six individual constituents, was able to distinguish between these in terms of different intermolecular interactions, akin to the recently reported analysis of a structure with four independent cation/anion pairs (Jotani et al., 2018).

\section{Computational study}

The co-crystal was subjected to intermolecular interaction energy calculations using CE-B3LYP/6-31G $(d, p)$ available in Crystal Explorer (version 17; Turner et al., 2017), with the crystal geometry being used as the input but, with hydrogenatom positions normalized to the standard neutron diffraction values. By default, a cluster of molecules (defined as density matrices) would need to be generated by applying crystallographic symmetry operations with respect to a selected central molecule (density matrix) within the radius of $3.8 \AA$ for interaction energy calculation (Turner et al., 2014). However, as the co-crystal contains multiple independent molecules in the asymmetric unit, a cluster of molecules was first generated surrounding the S1-molecule of TDBA for the calculation and then the procedure was repeated for the cluster of molecules surrounding the S2-molecule. The total intermolecular energy is the sum of energies of four main components comprising electrostatic, polarization, dispersion and exchange-repulsion with a scale factors of 1.057, 0.740, 0.871 and 0.618 , respectively (Mackenzie et al., 2017).

Selected results obtained from the interaction energy calculations involving the DTBA molecules as reference molecules are tabulated in Table 4 and the environment about the S1-molecule of TDBA is shown in Fig. 11. As expected, $\mathrm{O}-\mathrm{H} \cdots \mathrm{O}$ hydrogen bonding interactions give the greatest energies among the close contacts present in the crystal. The total intermolecular energy $\left(E_{\mathrm{tot}}\right)$ of the hydroxy-O$\mathrm{H} \cdots \mathrm{O}$ (oxide) hydrogen bonds is consistent across the series and lies in the range -50.7 to $-53.3 \mathrm{~kJ} \mathrm{~mol}^{-1}$. The other close contacts which exerts a relatively strong influence in the energy frameworks of the co-crystal are DTBA-phenyl-C$\mathrm{H} \cdots \mathrm{O}$ (oxide) interactions, with the $E_{\text {tot }}$ amounting of $c a$ $-40 \mathrm{~kJ} \mathrm{~mol}^{-1}$, Table 4. 
Table 4

Interaction energies $\left(\mathrm{kJ} \mathrm{mol}^{-1}\right)$ for selected close contacts.

\begin{tabular}{|c|c|c|c|c|c|c|}
\hline contact & $E_{\text {electrostatic }}$ & $E_{\text {polarization }}$ & $E_{\text {dispersion }}$ & $E_{\text {exchange-repulsion }}$ & $E_{\text {total }}$ & Symmetry operation \\
\hline $\mathrm{O} 6-\mathrm{H} 6 \mathrm{O} \cdots \mathrm{O} 4$ & -76.5 & -19.4 & -17.8 & 95.2 & -52.0 & $x, y, z$ \\
\hline $\mathrm{O} 8-\mathrm{H} 8 O \cdots \mathrm{O} 1$ & -72.8 & -19.2 & -14.9 & 82.3 & -53.3 & $1+x, y, z$ \\
\hline $\mathrm{O} 10-\mathrm{H} 10 O \cdots \mathrm{O} 2$ & -70.5 & -18.3 & -16.4 & 83.8 & -50.7 & $1+x, y, 1+z$ \\
\hline $\mathrm{C} 75-\mathrm{H} 75 \cdots \mathrm{O} 2$ & -16.8 & -6.6 & -41.6 & 29.8 & -40.4 & $1+x, y, z$ \\
\hline $\mathrm{C} 96-\mathrm{H} 96 \cdots \mathrm{O} 1$ & -15.2 & -6.1 & -42.0 & 27.9 & -40.0 & $x, y, z$ \\
\hline
\end{tabular}

\section{Database survey}

The only other structure of 2,2'-thiodibenzoic acid in the literature is that of the pure compound (Dai et al., 2005). While this presents essentially the same features as for the two independent molecules in (I), the dihedral angle between the thiophenyl rings is up to $4^{\circ}$ smaller at $68.0(2)^{\circ}$, and the tilts of the carboxylic acid groups are less pronounced at 6.9 (5) and $29.8(5)^{\circ}$.

A survey of the Cambridge Structural Database (Groom et al., 2016), revealed 110 molecules of (non-coordinated) triphenylphosphane oxide. A plot of the retrieved $\mathrm{P}=\mathrm{O}$ bond lengths is shown in Fig. 12. The mean value found for the $\mathrm{P}=\mathrm{O}$ bond length is $1.494 \AA$ with a standard deviation of $0.008 \AA$, with the minimum and maximum bond lengths being 1.478 (3) and 1.530 (7) $\AA$, found in the multi-component structures of NUCHIC (Okawa et al., 1997) and DUYXUQ (Arens et al., 1986), respectively. In the latter structure, charge-assisted hydrogen bonds are formed between $\mathrm{Ph}_{3} \mathrm{P}=\mathrm{O}$ and $\mathrm{Ph}_{3} \mathrm{P}=\mathrm{O}^{(+)} \mathrm{H}$. The observed $\mathrm{P}=\mathrm{O}$ bond lengths in (I), i.e. in the range 1.4975 (8) to 1.5018 (8) $\AA$ are at the lower end of the range of such bonds.

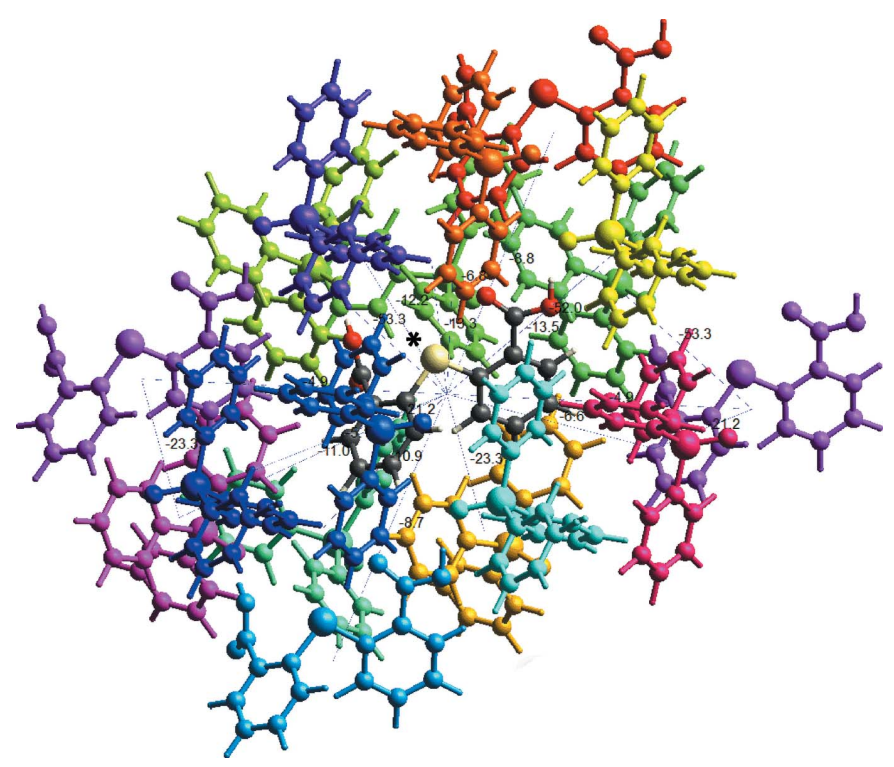

Figure 11

The interaction energy framework about the S1-molecule of DTBA (indicated by an asterisk) viewed along the $b$-axis direction.

\section{Synthesis and crystallization}

All chemical precursors were of reagent grade and used as received without purification. Thiosalicylic acid (Merck; $0.154 \mathrm{~g}, 0.001 \mathrm{~mol}$ ) and triphenylphosphane (Merck; $0.262 \mathrm{~g}$, $0.002 \mathrm{~mol})$ were dissolved in acetonitrile $(40 \mathrm{ml})$ and the mixture subsequently added into an acetonitrile solution $(25 \mathrm{ml})$ of copper(I) iodide (Merck; $0.19 \mathrm{~g}, 0.001 \mathrm{~mol})$. The reaction mixture was stirred for $1 \mathrm{~h}$ at room temperature before the white product was filtered, washed with cold ethanol and dried in vacuo. The filtrate was left at room temperature, yielding colourless prisms after 1 week; Yield 74\%. M.p. 457.7-459.2 K. IR ( $\left.\mathrm{cm}^{-1}\right): 3062 v(\mathrm{C}-\mathrm{H}), 1693$ $v(\mathrm{COO}), 1236 v(\mathrm{P}=\mathrm{O}), 1116 v(\mathrm{P}-\mathrm{Ar}), 719 \delta(\mathrm{P}-\mathrm{C}), 617$ $v(\mathrm{C}-\mathrm{S})$.

\section{Refinement}

Crystal data, data collection and structure refinement details are summarized in Table 5. The carbon-bound $\mathrm{H}$ atoms were placed in calculated positions $(\mathrm{C}-\mathrm{H}=0.93 \AA)$ and were included in the refinement in the riding-model approximation, with $U_{\text {iso }}(\mathrm{H})$ set to $1.2 U_{\text {eq }}(\mathrm{C})$. The oxygen-bound $\mathrm{H}$ atoms were located from difference Fourier maps and refined without constraint. Owing to poor agreement, three reflec-

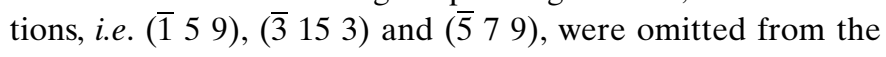
final cycles of refinement.

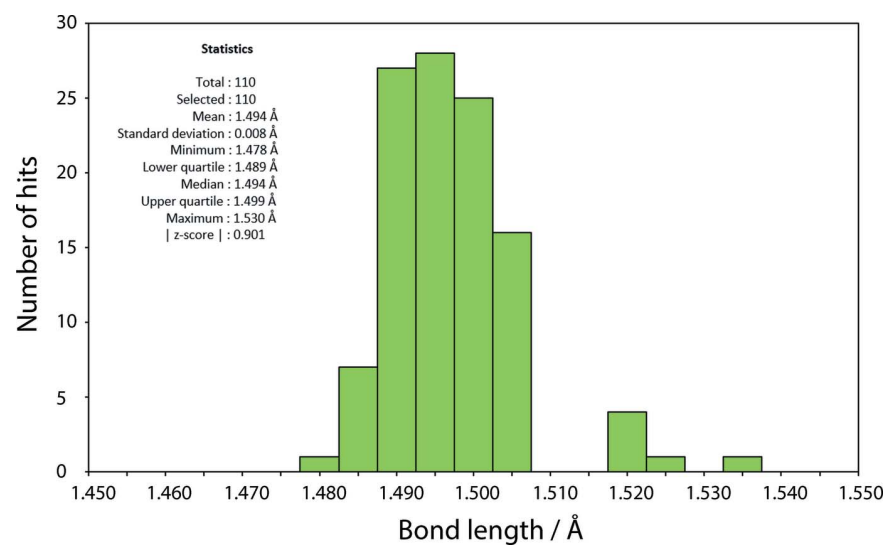

Figure 12

Statistical data on the $\mathrm{P}=\mathrm{O}$ bond lengths as calculated by Mogul (Bruno et al., 2004) 


\section{Funding information}

The support of Sunway University for studies in co-crystals, through Grant No. INT-FST-RCCM-2016-01, is gratefully acknowledged.

\section{References}

Arens, G., Sundermeyer, W. \& Pritzkow, H. (1986). Chem. Ber. 119, 3631-3638.

Bigham, M. \& Copes, R. (2005). Drug Saf. 28, 89-101.

Broker, G. A. \& Tiekink, E. R. T. (2007). CrystEngComm, 9, 10961109.

Bruno, I. J., Cole, J. C., Kessler, M., Luo, J., Motherwell, W. D. S., Purkis, L. H., Smith, B. R., Taylor, R., Cooper, R. I., Harris, S. E. \& Orpen, A. G. (2004). J. Chem. Inf. Comput. Sci. 44, 2133-2144.

Cang, J., Wang, C.-W., Chen, P.-C., Lin, Y.-J., Li, Y.-C. \& Chang, H.-T. (2017). Anal. Methods 9, 5254-5259.

Chien, C. W., Liu, C. L., Chen, F. J., Lin, K. H. \& Lin, C. S. (2012). Electrochim. Acta, 72, 74-80.

Dai, Y.-M., Huang, J.-F. \& Shen, H.-Y. (2005). Acta Cryst. E61, o3182o3183.

Dolomanov, O. V., Bourhis, L. J., Gildea, R. J., Howard, J. A. K. \& Puschmann, H. (2009). J. Appl. Cryst. 42, 339-341.

Farrugia, L. J. (2012). J. Appl. Cryst. 45, 849-854.

Gorobet, A., Vitiu, A., Petuhov, O. \& Croitor, L. (2018). Polyhedron, 151, 51-57.

Groom, C. R., Bruno, I. J., Lightfoot, M. P. \& Ward, S. C. (2016). Acta Cryst. B72, 171-179.

Jamaludin, N. S., Halim, S. N. A., Khoo, C.-H., Chen, B.-J., See, T.-H., Sim, J.-H., Cheah, Y.-K., Seng, H.-L. \& Tiekink, E. R. T. (2016). Z. Kristallogr. 231, 341-349.

Jotani, M. M., Wardell, J. L. \& Tiekink, E. R. T. (2018). Z. Kristallogr. Cryst. Mat. doi: https://doi. org/10.1515/zkri-2018-2101.

Mackenzie, C. F., Spackman, P. R., Jayatilaka, D. \& Spackman, M. A. (2017). IUCrJ, 4, 575-587.

Macrae, C. F., Edgington, P. R., McCabe, P., Pidcock, E., Shields, G. P., Taylor, R., Towler, M. \& van de Streek, J. (2006). J. Appl. Cryst. 39, 453-457.

McKinnon, J. J., Jayatilaka, D. \& Spackman, M. A. (2007). Chem. Commun. pp. 3814-3816.

Okawa, T., Osakada, N., Eguchi, S. \& Kakehi, A. (1997). Tetrahedron, 53, 16061-16082.

Rigaku OD (2018). CrysAlis PRO Software system. Rigaku Corporation, Oxford, UK.

Saha, M., Scerba, M. T., Shank, N. I., Hartman, T. L., Buchholz, C. A., Buckheit, R. W. Jr, Durell, S. R. \& Appella, D. H. (2017). ChemMedChem, 12, 714-721.

Schollmeyer, D., Shishkin, O. V., Rühl, T. \& Vysotsky, M. O. (2008). CrystEngComm, 10, 715-723.

Selig, P. S. \& Miller, S. J. (2011). Tetrahedron Lett. 52, 2148-2151.

Sheldrick, G. M. (2015a). Acta Cryst. A71, 3-8.

Sheldrick, G. M. (2015b). Acta Cryst. C71, 3-8.
Table 5

Experimental details.

Crystal data

Chemical formula

$M_{\mathrm{r}}$

Crystal system, space group

Temperature (K)

$a, b, c(\AA)$

$\beta\left({ }^{\circ}\right)$

$V\left(\AA^{3}\right)$

$Z$

Radiation type

$\mu\left(\mathrm{mm}^{-1}\right)$

Crystal size (mm)

Data collection

Diffractometer

Absorption correction

$T_{\min }, T_{\max }$

No. of measured, independent and observed $[I>2 \sigma(I)]$ reflections

$R_{\text {int }}$
$(\sin \theta / \lambda)_{\max }\left(\AA^{-1}\right)$

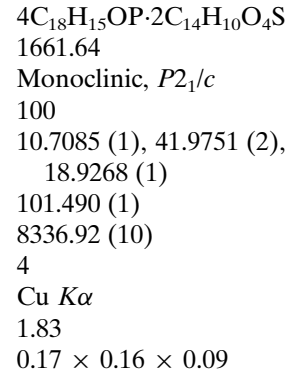

1661.64

Monoclinic, $P 2_{1} / c$

100

10.7085 (1), 41.9751 (2), $18.9268(1)$

$101.490(1)$

$8336.92(10)$

4

$\mathrm{Cu} K \alpha$

1.83

$0.17 \times 0.16 \times 0.09$

Refinement

$R\left[F^{2}>2 \sigma\left(F^{2}\right)\right], w R\left(F^{2}\right), S$

No. of reflections

No. of parameters

$\mathrm{H}$-atom treatment

XtaLAB Synergy, Dualflex,
AtlasS2
Gaussian (CrysAlis PRO; Rigaku
$\quad$ OD, 2018)
$0.653,1.000$
$94929,17036,15740$
0.025
0.630

$0.033,0.092,1.04$
17036
1079
H atoms treated by a mixture of
independent and constrained
refinement
$0.42,-0.55$

$\Delta \rho_{\max }, \Delta \rho_{\min }\left(\mathrm{e} \AA^{-3}\right)$ $0.42,-0.55$

Computer programs: CrysAlis PRO (Rigaku OD, 2018), SHELXT (Sheldrick, 2015a), SHELXL (Sheldrick, 2015b), ORTEP-3 for Windows (Farrugia, 2012), OLEX2

(Dolomanov et al., 2009), Mercury (Macrae et al., 2006) and publCIF (Westrip, 2010).

Sikarwar, B., Sharma, P. K., Srivastava, A., Agarwal, G. S., Boopathi, M., Singh, B. \& Jaiswal, Y. K. (2014). Biosens. Bioelectron. 60, 201209.

Spek, A. L. (2009). Acta Cryst. D65, 148-155.

Tiekink, E. R. T. \& Henderson, W. (2017). Coord. Chem. Rev. 341, 19-52.

Turner, M. J., Grabowsky, S., Jayatilaka, D. \& Spackman, M. A. (2014). J. Phys. Chem. Lett. 5, 4249-4255.

Turner, M. J., Mckinnon, J. J., Wolff, S. K., Grimwood, D. J., Spackman, P. R., Jayatilaka, D. \& Spackman, M. A. (2017). CrystalExplorer17. The University of Western Australia.

Wehr-Candler, T. \& Henderson, W. (2016). Coord. Chem. Rev. 313, 111-155.

Westrip, S. P. (2010). J. Appl. Cryst. 43, 920-925.

Yang, Q.-Q., Xiao, W., Du, W., Ouyang, Q. \& Chen, Y.-C. (2018). Chem. Commun. 54, 1129-1132. 


\section{supporting information}

Acta Cryst. (2018). E74, 1764-1771 [https://doi.org/10.1107/S205698901801544X]

\section{A 1:2 co-crystal of 2,2'-thiodibenzoic acid and triphenylphosphane oxide: crystal structure, Hirshfeld surface analysis and computational study}

\section{Sang Loon Tan and Edward R. T. Tiekink}

Computing details

Data collection: CrysAlis PRO (Rigaku OD, 2018); cell refinement: CrysAlis PRO (Rigaku OD, 2018); data reduction: CrysAlis PRO (Rigaku OD, 2018); program(s) used to solve structure: SHELXT (Sheldrick, 2015a); program(s) used to refine structure: SHELXL (Sheldrick, 2015b); molecular graphics: ORTEP-3 for Windows (Farrugia, 2012), OLEX2 (Dolomanov et al., 2009) and Mercury (Macrae et al., 2006); software used to prepare material for publication: publCIF (Westrip, 2010).

2-[(2-Carboxyphenyl)sulfanyl]benzoic acid-(diphenylphosphoryl)benzene (1/2)

Crystal data

$4 \mathrm{C}_{18} \mathrm{H}_{15} \mathrm{OP} \cdot 2 \mathrm{C}_{14} \mathrm{H}_{10} \mathrm{O}_{4} \mathrm{~S}$

$M_{r}=1661.64$

Monoclinic, $P 2_{1} / c$

$a=10.7085$ (1) $\AA$

$b=41.9751$ (2) $\AA$

$c=18.9268(1) \AA$

$\beta=101.490(1)^{\circ}$

$V=8336.92(10) \AA^{3}$

$Z=4$

$F(000)=3472$

$D_{\mathrm{x}}=1.324 \mathrm{Mg} \mathrm{m}^{-3}$

$\mathrm{Cu} K \alpha$ radiation, $\lambda=1.54184 \AA$

Cell parameters from 52739 reflections

$\theta=4.2-75.9^{\circ}$

$\mu=1.83 \mathrm{~mm}^{-1}$

$T=100 \mathrm{~K}$

Prism, colourless

$0.17 \times 0.16 \times 0.09 \mathrm{~mm}$

Data collection

XtaLAB Synergy, Dualflex, AtlasS2 diffractometer

Radiation source: micro-focus sealed X-ray tube, PhotonJet $(\mathrm{Cu}) \mathrm{X}$-ray Source

Mirror monochromator

Detector resolution: 5.2558 pixels $\mathrm{mm}^{-1}$

$\omega$ scans

Absorption correction: gaussian

(CrysAlis PRO; Rigaku OD, 2018)

$T_{\min }=0.653, T_{\max }=1.000$

94929 measured reflections

17036 independent reflections

15740 reflections with $I>2 \sigma(I)$

$R_{\text {int }}=0.025$

$\theta_{\text {max }}=76.2^{\circ}, \theta_{\text {min }}=3.2^{\circ}$

$h=-13 \rightarrow 13$

$k=-49 \rightarrow 52$

$l=-23 \rightarrow 23$

\section{Refinement}

Refinement on $F^{2}$

Least-squares matrix: full

$R\left[F^{2}>2 \sigma\left(F^{2}\right)\right]=0.033$

$w R\left(F^{2}\right)=0.092$

$S=1.04$

17036 reflections

1079 parameters

0 restraints

Primary atom site location: dual

Hydrogen site location: mixed

$\mathrm{H}$ atoms treated by a mixture of independent

and constrained refinement

$w=1 /\left[\sigma^{2}\left(F_{\mathrm{o}}^{2}\right)+(0.0481 P)^{2}+3.5049 P\right]$

where $P=\left(F_{\mathrm{o}}^{2}+2 F_{\mathrm{c}}^{2}\right) / 3$ 
$(\Delta / \sigma)_{\max }=0.003$

$\Delta \rho_{\min }=-0.55$ e $\AA^{-3}$

$\Delta \rho_{\max }=0.42$ e $\AA^{-3}$

Special details

Geometry. All esds (except the esd in the dihedral angle between two 1.s. planes) are estimated using the full covariance matrix. The cell esds are taken into account individually in the estimation of esds in distances, angles and torsion angles; correlations between esds in cell parameters are only used when they are defined by crystal symmetry. An approximate (isotropic) treatment of cell esds is used for estimating esds involving l.s. planes.

Fractional atomic coordinates and isotropic or equivalent isotropic displacement parameters $\left(\AA^{2}\right)$

\begin{tabular}{|c|c|c|c|c|}
\hline & $x$ & $y$ & $z$ & $U_{\text {iso }} * / U_{\text {eq }}$ \\
\hline S1 & $0.86876(3)$ & $0.60239(2)$ & $0.45382(2)$ & $0.01933(7)$ \\
\hline O5 & $0.66647(18)$ & $0.68394(3)$ & $0.41031(6)$ & $0.0653(5)$ \\
\hline O6 & $0.63653(11)$ & $0.64495(2)$ & $0.48314(5)$ & $0.0298(2)$ \\
\hline $\mathrm{H} 6 \mathrm{O}$ & $0.644(2)$ & $0.6616(5)$ & $0.5178(12)$ & $0.064(7)^{*}$ \\
\hline $\mathrm{O} 7$ & $1.05664(8)$ & $0.58755(2)$ & $0.57331(5)$ & $0.02348(19)$ \\
\hline $\mathrm{O} 8$ & $1.25159(9)$ & $0.57343(2)$ & $0.55791(5)$ & $0.0250(2)$ \\
\hline $\mathrm{H} 8 \mathrm{O}$ & $1.261(2)$ & $0.5646(5)$ & $0.6020(12)$ & $0.059(6)^{*}$ \\
\hline $\mathrm{C} 73$ & $0.57062(11)$ & $0.63409(3)$ & $0.30175(6)$ & $0.0189(2)$ \\
\hline $\mathrm{H} 73$ & 0.510504 & 0.650346 & 0.296861 & $0.023^{*}$ \\
\hline $\mathrm{C} 74$ & $0.56910(12)$ & $0.61279(3)$ & $0.24561(7)$ & $0.0208(2)$ \\
\hline $\mathrm{H} 74$ & 0.507892 & 0.614647 & 0.203416 & $0.025^{*}$ \\
\hline $\mathrm{C} 75$ & $0.65935(13)$ & $0.58870(3)$ & $0.25272(7)$ & $0.0231(3)$ \\
\hline H75 & 0.659019 & 0.574453 & 0.215058 & $0.028^{*}$ \\
\hline $\mathrm{C} 76$ & $0.75002(12)$ & $0.58580(3)$ & $0.31576(7)$ & $0.0227(3)$ \\
\hline H76 & 0.809779 & 0.569467 & 0.320215 & $0.027^{*}$ \\
\hline $\mathrm{C} 77$ & $0.75263(11)$ & $0.60713(3)$ & $0.37271(6)$ & $0.0180(2)$ \\
\hline $\mathrm{C} 78$ & $0.66130(11)$ & $0.63139(3)$ & $0.36547(6)$ & $0.0161(2)$ \\
\hline $\mathrm{C} 79$ & $0.65763(12)$ & $0.65610(3)$ & $0.42226(6)$ & $0.0198(2)$ \\
\hline $\mathrm{C} 80$ & $1.01153(11)$ & $0.61285(3)$ & $0.42513(6)$ & $0.0167(2)$ \\
\hline $\mathrm{C} 81$ & $1.01083(13)$ & $0.62905(3)$ & $0.36024(7)$ & $0.0234(3)$ \\
\hline $\mathrm{H} 81$ & 0.933478 & 0.633723 & 0.329907 & $0.028^{*}$ \\
\hline $\mathrm{C} 82$ & $1.12341(14)$ & $0.63818(4)$ & $0.34059(8)$ & $0.0297(3)$ \\
\hline H82 & 1.120595 & 0.648892 & 0.297281 & $0.036^{*}$ \\
\hline $\mathrm{C} 83$ & $1.24037(13)$ & $0.63157(4)$ & $0.38468(8)$ & $0.0294(3)$ \\
\hline H83 & 1.315681 & 0.638162 & 0.371782 & $0.035^{*}$ \\
\hline C84 & $1.24298(12)$ & $0.61502(3)$ & $0.44811(7)$ & $0.0232(3)$ \\
\hline H84 & 1.321038 & 0.610079 & 0.477425 & $0.028^{*}$ \\
\hline $\mathrm{C} 85$ & $1.13031(11)$ & $0.60555(3)$ & $0.46905(6)$ & $0.0168(2)$ \\
\hline C86 & $1.14015(11)$ & $0.58810(3)$ & $0.53863(6)$ & $0.0170(2)$ \\
\hline S2 & $0.36308(3)$ & $0.60471(2)$ & $0.95618(2)$ & $0.01877(7)$ \\
\hline O9 & $0.56354(8)$ & $0.58971(2)$ & $1.06759(4)$ & $0.02008(18)$ \\
\hline $\mathrm{O} 10$ & $0.75481(8)$ & $0.57505(2)$ & $1.04690(5)$ & $0.02276(19)$ \\
\hline $\mathrm{H} 10 \mathrm{O}$ & $0.766(2)$ & $0.5668(5)$ & $1.0924(12)$ & $0.060(6)^{*}$ \\
\hline O11 & $0.12548(13)$ & $0.68518(2)$ & $0.90397(5)$ & $0.0423(3)$ \\
\hline $\mathrm{O} 12$ & $0.15116(10)$ & $0.64745(2)$ & $0.98809(5)$ & $0.0254(2)$ \\
\hline $\mathrm{H} 12 \mathrm{O}$ & $0.1545(18)$ & $0.6638(5)$ & $1.0188(11)$ & $0.045(5)^{*}$ \\
\hline C87 & $0.48876(12)$ & $0.62911(3)$ & $0.85303(6)$ & $0.0184(2)$ \\
\hline
\end{tabular}




\begin{tabular}{|c|c|c|c|c|}
\hline H87 & 0.408551 & 0.634762 & 0.827278 & $0.022 *$ \\
\hline $\mathrm{C} 88$ & $0.59558(13)$ & $0.63654(3)$ & $0.82546(7)$ & $0.0231(3)$ \\
\hline H88 & 0.586377 & 0.647289 & 0.781755 & $0.028 *$ \\
\hline $\mathrm{C} 89$ & $0.71638(13)$ & $0.62809(3)$ & $0.86246(7)$ & $0.0253(3)$ \\
\hline H89 & 0.787995 & 0.632986 & 0.843699 & $0.030 *$ \\
\hline C90 & $0.72868(12)$ & $0.61226(3)$ & $0.92771(7)$ & $0.0213(2)$ \\
\hline H90 & 0.809347 & 0.606453 & 0.952545 & $0.026^{*}$ \\
\hline C91 & $0.62200(11)$ & $0.60484(3)$ & $0.95702(6)$ & $0.0154(2)$ \\
\hline C92 & 0.49939 (11) & $0.61319(3)$ & $0.91922(6)$ & $0.0151(2)$ \\
\hline C93 & $0.64177(11)$ & $0.58925(3)$ & $1.02911(6)$ & $0.0160(2)$ \\
\hline C94 & $0.24038(11)$ & $0.60750(3)$ & $0.87723(6)$ & $0.0179(2)$ \\
\hline C95 & $0.23738(12)$ & $0.58484(3)$ & $0.82279(7)$ & $0.0225(3)$ \\
\hline H95 & 0.297462 & 0.568554 & 0.828932 & $0.027^{*}$ \\
\hline C96 & $0.14576(12)$ & $0.58636(3)$ & $0.75969(7)$ & $0.0234(3)$ \\
\hline H96 & 0.145014 & 0.571214 & 0.723745 & $0.028^{*}$ \\
\hline C97 & $0.05526(12)$ & $0.61046(3)$ & $0.75020(7)$ & $0.0223(3)$ \\
\hline H97 & -0.006374 & 0.611467 & 0.708014 & $0.027^{*}$ \\
\hline C98 & $0.05714(11)$ & $0.63302(3)$ & $0.80384(6)$ & $0.0194(2)$ \\
\hline H98 & -0.003174 & 0.649254 & 0.797145 & $0.023 *$ \\
\hline C99 & $0.14835(11)$ & $0.63174(3)$ & $0.86788(6)$ & $0.0164(2)$ \\
\hline $\mathrm{C} 100$ & $0.14237(11)$ & $0.65763(3)$ & $0.92171(6)$ & $0.0181(2)$ \\
\hline $\mathrm{P} 1$ & $0.45306(3)$ & $0.53046(2)$ & $0.69428(2)$ & $0.01230(6)$ \\
\hline $\mathrm{O} 1$ & $0.32078(8)$ & $0.54411(2)$ & $0.67897(4)$ & $0.01763(17)$ \\
\hline $\mathrm{C} 1$ & $0.61145(11)$ & $0.53439(3)$ & $0.83070(6)$ & $0.0167(2)$ \\
\hline H1 & 0.656091 & 0.550177 & 0.811734 & $0.020^{*}$ \\
\hline $\mathrm{C} 2$ & $0.65061(12)$ & $0.52494(3)$ & $0.90237(6)$ & $0.0192(2)$ \\
\hline $\mathrm{H} 2$ & 0.721498 & 0.534351 & 0.931197 & $0.023 *$ \\
\hline $\mathrm{C} 3$ & $0.58344(12)$ & $0.50146(3)$ & $0.93049(6)$ & $0.0194(2)$ \\
\hline H3 & 0.610599 & 0.494813 & 0.977939 & $0.023^{*}$ \\
\hline $\mathrm{C} 4$ & $0.47584(12)$ & $0.48781(3)$ & $0.88817(7)$ & $0.0203(2)$ \\
\hline H4 & 0.430003 & 0.472469 & 0.907717 & $0.024 *$ \\
\hline $\mathrm{C} 5$ & $0.43666(11)$ & $0.49703(3)$ & $0.81683(6)$ & $0.0176(2)$ \\
\hline H5 & 0.364754 & 0.487840 & 0.788474 & $0.021^{*}$ \\
\hline C6 & $0.50568(11)$ & $0.52020(3)$ & $0.78760(6)$ & $0.0136(2)$ \\
\hline C7 & $0.53838(12)$ & $0.46861(3)$ & $0.66991(7)$ & $0.0198(2)$ \\
\hline H7 & 0.588550 & 0.469321 & 0.716034 & $0.024^{*}$ \\
\hline $\mathrm{C} 8$ & $0.54019(13)$ & $0.44169(3)$ & $0.62722(8)$ & $0.0254(3)$ \\
\hline H8 & 0.592086 & 0.424523 & 0.644795 & $0.030^{*}$ \\
\hline C9 & $0.46540(14)$ & $0.44035(3)$ & $0.55898(8)$ & $0.0306(3)$ \\
\hline H9 & 0.466881 & 0.422331 & 0.530569 & $0.037^{*}$ \\
\hline $\mathrm{C} 10$ & $0.38826(17)$ & $0.46583(4)$ & $0.53291(8)$ & $0.0403(4)$ \\
\hline H10 & 0.337265 & 0.464822 & 0.487039 & $0.048^{*}$ \\
\hline $\mathrm{C} 11$ & $0.38629(15)$ & $0.49291(4)$ & $0.57465(7)$ & $0.0312(3)$ \\
\hline H11 & 0.334659 & 0.510043 & 0.556555 & $0.037^{*}$ \\
\hline $\mathrm{C} 12$ & $0.46162(11)$ & $0.49447(3)$ & $0.64372(6)$ & $0.0160(2)$ \\
\hline $\mathrm{C} 13$ & $0.68681(11)$ & $0.54783(3)$ & $0.66017(6)$ & $0.0168(2)$ \\
\hline H13 & 0.710047 & 0.526522 & 0.666794 & $0.020^{*}$ \\
\hline C14 & $0.77099(12)$ & $0.56959(3)$ & $0.63990(6)$ & $0.0203(2)$ \\
\hline
\end{tabular}




\begin{tabular}{|c|c|c|c|c|}
\hline H14 & 0.850763 & 0.562941 & 0.633391 & $0.024^{*}$ \\
\hline $\mathrm{C} 15$ & $0.73532(12)$ & $0.60136(3)$ & $0.62942(7)$ & 0.0223 \\
\hline H15 & 0.790696 & 0.615862 & 0.614766 & $0.027^{*}$ \\
\hline C16 & $0.61775(13)$ & $0.61152(3)$ & $0.64067(7)$ & 0.0228 \\
\hline H16 & 0.595084 & 0.632870 & 0.634256 & $0.027^{*}$ \\
\hline $\mathrm{C} 17$ & $0.53354(12)$ & $0.58992(3)$ & $0.66151(6)$ & $0.0187(2)$ \\
\hline H17 & 0.454903 & 0.596820 & 0.669357 & $0.022 *$ \\
\hline $\mathrm{C} 18$ & $0.56734(11)$ & 0.55785 & $0.67064(6)$ & $0.0141(2)$ \\
\hline P2 & -0.04151 & $0.53337(2)$ & $0.18925(2)$ & $0.01230(6)$ \\
\hline $\mathrm{O} 2$ & $-0.17363(8)$ & $0.54704(2)$ & $0.17137(4)$ & $0.01732(17)$ \\
\hline C19 & $0.11406(11)$ & $0.53774(3)$ & $0.32684(6)$ & $0.0167(2)$ \\
\hline H19 & 0.160010 & 0.553259 & 0.307909 & $0.020^{*}$ \\
\hline $\mathrm{C} 20$ & $0.15104(12)$ & $0.52863(3)$ & $0.39889(6)$ & $0.0194(2)$ \\
\hline $\mathrm{H} 20$ & 0.221743 & 0.538005 & 0.427976 & $0.023^{*}$ \\
\hline $\mathrm{C} 21$ & $0.08202(12)$ & $0.50557(3)$ & $0.42697(6)$ & 0.0205 \\
\hline $\mathrm{H} 21$ & 0.107516 & 0.499240 & 0.474765 & $0.025^{*}$ \\
\hline $\mathrm{C} 22$ & $-0.02503(12)$ & $0.49184(3)$ & $0.38417(7)$ & $0.0211(2)$ \\
\hline $\mathrm{H} 22$ & -0.071898 & 0.476702 & 0.403634 & $0.025^{*}$ \\
\hline $\mathrm{C} 23$ & -0.06198 & $0.50071(3)$ & $0.31239(6)$ & $0.0176(2)$ \\
\hline $\mathrm{H} 23$ & -0.133366 & 0.491457 & 0.283687 & $0.021^{*}$ \\
\hline $\mathrm{C} 24$ & $0.00844(11)$ & $0.52362(3)$ & $0.28324(6)$ & $0.0139(2)$ \\
\hline $\mathrm{C} 25$ & $0.04771(12)$ & $0.47170(3)$ & $0.16729(6)$ & $0.0187(2)$ \\
\hline $\mathrm{H} 25$ & 0.099716 & 0.473162 & 0.212801 & $0.022 *$ \\
\hline $\mathrm{C} 26$ & $0.04960(12)$ & $0.44426(3)$ & $0.12632(7)$ & $0.0226(3)$ \\
\hline $\mathrm{H} 26$ & 0.103258 & 0.427486 & 0.144451 & $0.027^{*}$ \\
\hline $\mathrm{C} 27$ & $-0.02776(13)$ & $0.44180(3)$ & $0.05889(7)$ & 0.0257 \\
\hline $\mathrm{H} 27$ & -0.025983 & 0.423458 & 0.031542 & $0.031 *$ \\
\hline $\mathrm{C} 28$ & $-0.10793(15)$ & $0.46669(4)$ & $0.03213(8)$ & 0.0345 \\
\hline $\mathrm{H} 28$ & -0.160726 & 0.464959 & -0.013102 & $0.041^{*}$ \\
\hline $\mathrm{C} 29$ & $-0.11000(14)$ & $0.49422(3)$ & $0.07241(7)$ & 0.0280 \\
\hline $\mathrm{H} 29$ & -0.163834 & 0.510912 & 0.053961 & $0.034 *$ \\
\hline $\mathrm{C} 30$ & $-0.03175(11)$ & $0.49697(3)$ & $0.14038(6)$ & $0.0151(2)$ \\
\hline $\mathrm{C} 31$ & $0.03988(12)$ & $0.59295(3)$ & $0.15930(7)$ & $0.0192(2)$ \\
\hline H31 & -0.039378 & 0.599663 & 0.166545 & $0.023^{*}$ \\
\hline C32 & $0.12523(13)$ & $0.61484(3)$ & $0.14071(7)$ & 0.0234 \\
\hline $\mathrm{H} 32$ & 0.102725 & 0.636236 & 0.135335 & $0.028 *$ \\
\hline C33 & $0.24365(12)$ & $0.60499(3)$ & $0.13014(7)$ & $0.0212(3)$ \\
\hline H33 & 0.299701 & 0.619741 & 0.117004 & $0.025^{*}$ \\
\hline C34 & $0.27898(11)$ & $0.57320(3)$ & $0.13908(6)$ & $0.0193(2)$ \\
\hline H34 & 0.359108 & 0.566710 & 0.132823 & $0.023 *$ \\
\hline C35 & $0.19411(11)$ & 0.55108 & $0.15742(6)$ & $0.0161(2)$ \\
\hline H35 & 0.217465 & 0.529756 & 0.163287 & $0.019^{*}$ \\
\hline C36 & $0.07374(11)$ & $0.56081(3)$ & $0.16705(6)$ & $0.0142(2)$ \\
\hline P3 & $0.09805(3)$ & $0.71259(2)$ & $0.12227(2)$ & $0.01599(7)$ \\
\hline $\mathrm{O} 3$ & $0.17981(8)$ & $0.69166(2)$ & $0.08605(5)$ & $0.02155(18)$ \\
\hline C37 & $-0.08417(12)$ & $0.68424(3)$ & $0.19179(7)$ & $0.0244(3)$ \\
\hline H37 & -0.030988 & 0.688982 & 0.235659 & $0.029^{*}$ \\
\hline C38 & $-0.19660(13)$ & $0.66742(3)$ & $0.19036(8)$ & 0.0315 \\
\hline
\end{tabular}




\begin{tabular}{|c|c|c|c|c|}
\hline $\mathrm{H} 38$ & -0.218007 & 0.660839 & 0.233340 & $0.038^{*}$ \\
\hline C39 & $-0.27655(13)$ & $0.66046(3)$ & $0.12557(9)$ & $0.0312(3)$ \\
\hline H39 & -0.351472 & 0.649149 & 0.124875 & $0.037^{*}$ \\
\hline $\mathrm{C} 40$ & $-0.24498(14)$ & $0.67032(3)$ & $0.06181(8)$ & $0.0323(3)$ \\
\hline $\mathrm{H} 40$ & -0.299242 & 0.665798 & 0.018164 & $0.039 *$ \\
\hline $\mathrm{C} 41$ & $-0.13297(14)$ & $0.68691(3)$ & $0.06245(7)$ & $0.0274(3)$ \\
\hline H41 & -0.112158 & 0.693373 & 0.019234 & $0.033 *$ \\
\hline $\mathrm{C} 42$ & $-0.05124(12)$ & $0.69397(3)$ & $0.12764(7)$ & $0.0185(2)$ \\
\hline $\mathrm{C} 43$ & $-0.03715(12)$ & $0.76945(3)$ & $0.08915(8)$ & $0.0248(3)$ \\
\hline $\mathrm{H} 43$ & -0.081000 & 0.764003 & 0.125165 & $0.030^{*}$ \\
\hline $\mathrm{C} 44$ & $-0.06608(13)$ & $0.79759(3)$ & $0.05104(8)$ & $0.0299(3)$ \\
\hline $\mathrm{H} 44$ & -0.128479 & 0.811110 & 0.061853 & $0.036^{*}$ \\
\hline $\mathrm{C} 45$ & $-0.00170(14)$ & $0.80552(3)$ & $-0.00327(8)$ & $0.0316(3)$ \\
\hline $\mathrm{H} 45$ & -0.021237 & 0.824361 & -0.028957 & $0.038^{*}$ \\
\hline $\mathrm{C} 46$ & $0.09146(14)$ & $0.78551(3)$ & $-0.01936(8)$ & $0.0305(3)$ \\
\hline H46 & 0.134234 & 0.790946 & -0.055853 & $0.037^{*}$ \\
\hline $\mathrm{C} 47$ & $0.12140(12)$ & $0.75730(3)$ & $0.01881(7)$ & $0.0239(3)$ \\
\hline $\mathrm{H} 47$ & 0.183816 & 0.743850 & 0.007752 & $0.029^{*}$ \\
\hline $\mathrm{C} 48$ & $0.05757(12)$ & $0.74923(3)$ & $0.07371(7)$ & $0.0193(2)$ \\
\hline $\mathrm{C} 49$ & $0.29856(12)$ & $0.70791(3)$ & $0.23785(7)$ & $0.0233(3)$ \\
\hline H49 & 0.334641 & 0.694746 & 0.207831 & $0.028^{*}$ \\
\hline $\mathrm{C} 50$ & $0.36378(13)$ & $0.71402(3)$ & $0.30779(8)$ & $0.0293(3)$ \\
\hline $\mathrm{H} 50$ & 0.443912 & 0.705170 & 0.324258 & $0.035^{*}$ \\
\hline $\mathrm{C} 51$ & $0.30930(14)$ & $0.73330(3)$ & $0.35291(8)$ & $0.0312(3)$ \\
\hline H51 & 0.352266 & 0.736994 & 0.399933 & $0.037^{*}$ \\
\hline C52 & $0.19116(14)$ & $0.74706(3)$ & $0.32820(8)$ & $0.0308(3)$ \\
\hline H52 & 0.155341 & 0.760138 & 0.358497 & $0.037^{*}$ \\
\hline $\mathrm{C} 53$ & $0.12620(13)$ & $0.74136(3)$ & $0.25837(7)$ & $0.0253(3)$ \\
\hline $\mathrm{H} 53$ & 0.047151 & 0.750767 & 0.241795 & $0.030^{*}$ \\
\hline $\mathrm{C} 54$ & $0.17919(12)$ & $0.72151(3)$ & $0.21276(7)$ & $0.0188(2)$ \\
\hline P4 & $0.59434(3)$ & $0.71241(2)$ & $0.62054(2)$ & $0.01558(7)$ \\
\hline $\mathrm{O} 4$ & $0.65852(8)$ & $0.68597(2)$ & $0.58832(4)$ & $0.01947(18)$ \\
\hline $\mathrm{C} 55$ & $0.36994(13)$ & $0.67928(3)$ & $0.59742(8)$ & $0.0282(3)$ \\
\hline H55 & 0.389594 & 0.674863 & 0.552729 & $0.034 *$ \\
\hline $\mathrm{C} 56$ & $0.26067(15)$ & $0.66662(4)$ & $0.61513(9)$ & $0.0361(3)$ \\
\hline H56 & 0.206716 & 0.653874 & 0.582208 & $0.043^{*}$ \\
\hline $\mathrm{C} 57$ & $0.23188(14)$ & $0.67296(4)$ & $0.68190(9)$ & $0.0357(3)$ \\
\hline H57 & 0.158804 & 0.664312 & 0.693791 & $0.043 *$ \\
\hline $\mathrm{C} 58$ & $0.31085(14)$ & $0.69200(4)$ & $0.73083(8)$ & $0.0324(3)$ \\
\hline $\mathrm{H} 58$ & 0.290945 & 0.696173 & 0.775564 & $0.039^{*}$ \\
\hline C59 & $0.42035(13)$ & $0.70500(3)$ & $0.71334(7)$ & $0.0248(3)$ \\
\hline H59 & 0.473371 & 0.717929 & 0.746290 & $0.030 *$ \\
\hline C60 & $0.45058(12)$ & $0.69863(3)$ & $0.64644(7)$ & $0.0190(2)$ \\
\hline C61 & $0.77928(13)$ & $0.70565(3)$ & $0.74264(7)$ & $0.0256(3)$ \\
\hline H61 & 0.789190 & 0.685356 & 0.724829 & $0.031 *$ \\
\hline C62 & $0.85001(14)$ & $0.71467(4)$ & $0.80939(8)$ & $0.0328(3)$ \\
\hline H62 & 0.907827 & 0.700498 & 0.835864 & $0.039^{*}$ \\
\hline C63 & $0.83457(14)$ & $0.74466(4)$ & $0.83647(7)$ & $0.0310(3)$ \\
\hline
\end{tabular}




$\begin{array}{lllll}\text { H63 } & 0.880548 & 0.750466 & 0.881635 & 0.037^{*} \\ \text { C64 } & 0.75106(15) & 0.76599(4) & 0.79662(8) & 0.0351(3) \\ \text { H64 } & 0.741536 & 0.786242 & 0.814744 & 0.042^{*} \\ \text { C65 } & 0.68114(14) & 0.75731(3) & 0.72948(8) & 0.0313(3) \\ \text { H65 } & 0.625732 & 0.771861 & 0.702523 & 0.038^{*} \\ \text { C66 } & 0.69371(11) & 0.72688(3) & 0.70238(7) & 0.0191(2) \\ \text { C67 } & 0.45982(12) & 0.76745(3) & 0.56674(7) & 0.0231(3) \\ \text { H67 } & 0.417547 & 0.765712 & 0.604988 & 0.028^{*} \\ \text { C68 } & 0.43043(13) & 0.79226(3) & 0.51757(8) & 0.0275(3) \\ \text { H68 } & 0.369387 & 0.807282 & 0.523296 & 0.033^{*} \\ \text { C69 } & 0.49220(13) & 0.79458(3) & 0.46002(8) & 0.0283(3) \\ \text { H69 } & 0.472196 & 0.811139 & 0.427055 & 0.034^{*} \\ \text { C70 } & 0.58383(13) & 0.77230(3) & 0.45135(7) & 0.0261(3) \\ \text { H70 } & 0.624512 & 0.773921 & 0.412430 & 0.031^{*} \\ \text { C71 } & 0.61497(12) & 0.74760(3) & 0.50053(7) & 0.0207(2) \\ \text { H71 } & 0.676790 & 0.732791 & 0.494812 & 0.025^{*} \\ \text { C72 } & 0.55292(11) & 0.74510(3) & 0.55873(7) & 0.0183(2) \\ \end{array}$

Atomic displacement parameters $\left(\AA^{2}\right)$

\begin{tabular}{|c|c|c|c|c|c|c|}
\hline & $U^{11}$ & $U^{22}$ & $U^{33}$ & $U^{12}$ & $U^{13}$ & $U^{23}$ \\
\hline $\mathrm{S} 1$ & $0.01503(14)$ & $0.02690(16)$ & $0.01590(14)$ & $0.00414(11)$ & $0.00267(11)$ & $0.00504(11)$ \\
\hline O5 & $0.1541(15)$ & $0.0195(5)$ & $0.0287(6)$ & $-0.0136(7)$ & $0.0334(8)$ & -0.0030 \\
\hline O6 & $0.0519(6)$ & $0.0196(5)$ & $0.0228(5)$ & $-0.0019(4)$ & 0.0189 (4) & $-0.0022(4)$ \\
\hline $\mathrm{O} 7$ & 0.0198 (4) & $0.0312(5)$ & $0.0197(4)$ & $0.0043(4)$ & $0.0047(3)$ & $0.0069(4)$ \\
\hline O8 & $0.0187(4)$ & $0.0351(5)$ & $0.0200(4)$ & $0.0091(4)$ & $0.0011(3)$ & 0.0089 \\
\hline C73 & $0.0162(5)$ & $0.0211(6)$ & 0.0188 (6) & $0.0022(5)$ & $0.0022(4)$ & $0.0008(5)$ \\
\hline $\mathrm{C} 74$ & $0.0175(6)$ & $0.0274(6)$ & $0.0164(6)$ & $-0.0040(5)$ & 0.0004 & $-0.0018(5)$ \\
\hline $\mathrm{C} 75$ & $0.0251(6)$ & $0.0255(6)$ & $0.0194(6)$ & $-0.0024(5)$ & 0.0065 & $-0.0073(5)$ \\
\hline C76 & $0.0211(6)$ & $0.0232(6)$ & $0.0249(6)$ & $0.0056(5)$ & $0.0072(5)$ & $-0.0028(5)$ \\
\hline C77 & $0.0162(5)$ & $0.0206(6)$ & $0.0170(5)$ & $0.0017(5)$ & 0.0028 & $0.0014(5)$ \\
\hline $\mathrm{C} 78$ & $0.0160(5)$ & $0.0161(5)$ & $0.0164(5)$ & $0.0000(4)$ & $0.0037(4)$ & $0.0006(4)$ \\
\hline C79 & $0.0234(6)$ & $0.0185(6)$ & $0.0165(6)$ & $0.0024(5)$ & $0.0018(5)$ & $0.0007(5)$ \\
\hline $\mathrm{C} 80$ & $0.0186(6)$ & $0.0154(5)$ & $0.0164(5)$ & $0.0031(4)$ & $0.0042(4)$ & $0.0003(4)$ \\
\hline $\mathrm{C} 81$ & $0.0235(6)$ & $0.0277(7)$ & $0.0192(6)$ & $0.0062(5)$ & $0.0046(5)$ & $0.0069(5)$ \\
\hline $\mathrm{C} 82$ & $0.0310(7)$ & $0.0344(7)$ & $0.0262(7)$ & $0.0060(6)$ & $0.0116(6)$ & $0.0128(6)$ \\
\hline $\mathrm{C} 83$ & $0.0246(7)$ & $0.0337(7)$ & $0.0334(7)$ & $0.0006(6)$ & $0.0139(6)$ & 0.0093 (6) \\
\hline $\mathrm{C} 84$ & 0.0177 (6) & $0.0260(6)$ & $0.0260(6)$ & $0.0022(5)$ & $0.0044(5)$ & $0.0043(5)$ \\
\hline $\mathrm{C} 85$ & $0.0190(6)$ & $0.0149(5)$ & $0.0165(5)$ & 0.0018 (4) & $0.0037(4)$ & 0.0003 (4) \\
\hline C86 & $0.0165(5)$ & $0.0161(5)$ & $0.0168(5)$ & $0.0009(4)$ & -0.0005 & -0.0003 \\
\hline $\mathrm{S} 2$ & $0.01312(13)$ & $0.02878(16)$ & $0.01450(13)$ & $0.00328(11)$ & $0.00294(10)$ & 0.00385 \\
\hline O9 & $0.0180(4)$ & $0.0253(4)$ & $0.0169(4)$ & $0.0024(3)$ & 0.0033 & 0.0036 \\
\hline $\mathrm{O} 10$ & $0.0172(4)$ & $0.0317(5)$ & $0.0182(4)$ & 0.0088 & 0.0007 & $0.0046(4)$ \\
\hline O11 & $0.0794(9)$ & $0.0169(5)$ & $0.0236(5)$ & $-0.0017(5)$ & $-0.0069(5)$ & 0.0018 \\
\hline $\mathrm{O} 12$ & $0.0420(6)$ & $0.0184(4)$ & $0.0189(4)$ & $0.0065(4)$ & $0.0136(4)$ & $0.0013(4)$ \\
\hline $\mathrm{C} 87$ & $0.0184(6)$ & $0.0192(6)$ & $0.0168(5)$ & $0.0033(5)$ & $0.0016(4)$ & $0.0022(4)$ \\
\hline C88 & $0.0278(7)$ & $0.0233(6)$ & $0.0196(6)$ & $0.0017(5)$ & $0.0083(5)$ & 0.0060 \\
\hline C89 & $0.0212(6)$ & $0.0294(7)$ & $0.0281(7)$ & $0.0002(5)$ & $0.0118(5)$ & $0.0054(5)$ \\
\hline
\end{tabular}




\begin{tabular}{|c|c|c|c|c|c|c|}
\hline C90 & $0.0159(6)$ & $0.0238(6)$ & $0.0246(6)$ & $0.0019(5)$ & $0.0050(5)$ & $0.0021(5)$ \\
\hline C91 & $0.0152(5)$ & $0.0150(5)$ & $0.0157(5)$ & $0.0013(4)$ & $0.0027(4)$ & $-0.0007(4)$ \\
\hline C92 & $0.0166(5)$ & $0.0137(5)$ & $0.0152(5)$ & $0.0014(4)$ & $0.0037(4)$ & $-0.0008(4)$ \\
\hline C93 & $0.0154(5)$ & $0.0150(5)$ & $0.0162(5)$ & $0.0005(4)$ & $-0.0003(4)$ & $-0.0012(4)$ \\
\hline C94 & $0.0138(5)$ & $0.0237(6)$ & $0.0167(5)$ & $-0.0001(5)$ & $0.0037(4)$ & $0.0023(5)$ \\
\hline C95 & $0.0187(6)$ & $0.0264(6)$ & $0.0236(6)$ & $0.0027(5)$ & $0.0073(5)$ & $-0.0017(5)$ \\
\hline C96 & $0.0227(6)$ & $0.0292(7)$ & $0.0193(6)$ & $-0.0042(5)$ & $0.0063(5)$ & $-0.0050(5)$ \\
\hline C97 & $0.0177(6)$ & $0.0309(7)$ & $0.0167(6)$ & $-0.0058(5)$ & $-0.0003(5)$ & $-0.0003(5)$ \\
\hline C98 & $0.0151(5)$ & $0.0234(6)$ & $0.0193(6)$ & $-0.0011(5)$ & $0.0024(5)$ & $0.0035(5)$ \\
\hline C99 & $0.0142(5)$ & $0.0186(6)$ & $0.0166(5)$ & $-0.0027(4)$ & $0.0036(4)$ & $0.0027(4)$ \\
\hline $\mathrm{C} 100$ & $0.0155(5)$ & $0.0191(6)$ & $0.0179(6)$ & $-0.0015(4)$ & $-0.0007(4)$ & $0.0024(5)$ \\
\hline $\mathrm{P} 1$ & $0.01150(13)$ & $0.01351(13)$ & $0.01110(13)$ & $0.00026(10)$ & $0.00034(10)$ & $0.00070(10)$ \\
\hline $\mathrm{O} 1$ & $0.0128(4)$ & $0.0217(4)$ & $0.0176(4)$ & $0.0025(3)$ & 0.0013 & $0.0031(3)$ \\
\hline $\mathrm{C} 1$ & $0.0172(6)$ & $0.0182(5)$ & $0.0144(5)$ & $-0.0027(4)$ & $0.0023(4)$ & $-0.0004(4)$ \\
\hline $\mathrm{C} 2$ & $0.0172(6)$ & $0.0259(6)$ & $0.0133(5)$ & $-0.0021(5)$ & $-0.0001(4)$ & $-0.0022(5)$ \\
\hline $\mathrm{C} 3$ & $0.0210(6)$ & $0.0254(6)$ & $0.0120(5)$ & $0.0037(5)$ & $0.0035(4)$ & $0.0022(5)$ \\
\hline $\mathrm{C} 4$ & $0.0228(6)$ & $0.0210(6)$ & $0.0180(6)$ & $-0.0027(5)$ & $0.0062(5)$ & $0.0037(5)$ \\
\hline $\mathrm{C} 5$ & $0.0172(5)$ & $0.0188(6)$ & $0.0161(5)$ & $-0.0027(5)$ & $0.0014(4)$ & $-0.0002(4)$ \\
\hline C6 & $0.0146(5)$ & $0.0137(5)$ & $0.0125(5)$ & 0.0017 (4) & $0.0024(4)$ & -0.0003 \\
\hline $\mathrm{C} 7$ & $0.0202(6)$ & $0.0193(6)$ & $0.0196(6)$ & $0.0003(5)$ & $0.0030(5)$ & $-0.0023(5)$ \\
\hline $\mathrm{C} 8$ & $0.0257(7)$ & $0.0180(6)$ & $0.0349(7)$ & $-0.0006(5)$ & $0.0118(6)$ & $-0.0047(5)$ \\
\hline C9 & $0.0329(7)$ & $0.0278(7)$ & $0.0336(7)$ & $-0.0083(6)$ & $0.0124(6)$ & $-0.0168(6)$ \\
\hline $\mathrm{C} 10$ & $0.0489(10)$ & $0.0429(9)$ & $0.0232(7)$ & $0.0014(7)$ & $-0.0069(7)$ & $-0.0169(6)$ \\
\hline $\mathrm{C} 11$ & $0.0382(8)$ & $0.0311(7)$ & $0.0190(6)$ & $0.0060(6)$ & $-0.0069(6)$ & $-0.0056(5)$ \\
\hline $\mathrm{C} 12$ & $0.0155(5)$ & $0.0173(5)$ & $0.0149(5)$ & $-0.0032(4)$ & $0.0026(4)$ & $-0.0016(4)$ \\
\hline $\mathrm{C} 13$ & $0.0167(5)$ & $0.0175(5)$ & $0.0153(5)$ & $0.0000(4)$ & $0.0015(4)$ & $-0.0014(4)$ \\
\hline $\mathrm{C} 14$ & $0.0156(5)$ & $0.0280(6)$ & $0.0172(6)$ & $-0.0037(5)$ & $0.0032(4)$ & $-0.0022(5)$ \\
\hline $\mathrm{C} 15$ & $0.0227(6)$ & $0.0253(6)$ & $0.0175(6)$ & $-0.0089(5)$ & $0.0009(5)$ & $0.0035(5)$ \\
\hline $\mathrm{C} 16$ & $0.0272(7)$ & $0.0166(6)$ & $0.0232(6)$ & $-0.0022(5)$ & $0.0016(5)$ & $0.0043(5)$ \\
\hline $\mathrm{C} 17$ & $0.0186(6)$ & $0.0174(6)$ & $0.0195(6)$ & $0.0016(5)$ & $0.0024(5)$ & 0.0015 \\
\hline C18 & $0.0155(5)$ & $0.0162(5)$ & $0.0096(5)$ & -0.0013 & $0.0000(4)$ & $0.0002(4)$ \\
\hline $\mathrm{P} 2$ & $0.01140(13)$ & $0.01358(13)$ & $0.01122(13)$ & $0.00096(10)$ & $0.00054(10)$ & $0.00039(10)$ \\
\hline $\mathrm{O} 2$ & $0.0131(4)$ & $0.0211(4)$ & $0.0170(4)$ & $0.0036(3)$ & $0.0013(3)$ & $0.0014(3)$ \\
\hline C19 & $0.0175(6)$ & $0.0175(5)$ & $0.0151(5)$ & $-0.0020(4)$ & $0.0028(4)$ & $-0.0006(4)$ \\
\hline $\mathrm{C} 20$ & $0.0178(6)$ & $0.0253(6)$ & $0.0136(5)$ & $-0.0021(5)$ & $-0.0002(4)$ & $-0.0030(5)$ \\
\hline $\mathrm{C} 21$ & $0.0222(6)$ & $0.0265(6)$ & $0.0126(5)$ & $0.0023(5)$ & $0.0031(5)$ & $0.0018(5)$ \\
\hline $\mathrm{C} 22$ & $0.0235(6)$ & $0.0232(6)$ & $0.0171(6)$ & $-0.0031(5)$ & $0.0058(5)$ & $0.0032(5)$ \\
\hline $\mathrm{C} 23$ & $0.0169(5)$ & $0.0193(6)$ & $0.0159(5)$ & $-0.0023(5)$ & $0.0019(4)$ & -0.0003 \\
\hline $\mathrm{C} 24$ & $0.0148(5)$ & $0.0140(5)$ & $0.0129(5)$ & $0.0023(4)$ & $0.0027(4)$ & -0.0005 \\
\hline $\mathrm{C} 25$ & $0.0184(6)$ & $0.0192(6)$ & $0.0176(6)$ & $0.0011(5)$ & $0.0013(5)$ & $-0.0015(5)$ \\
\hline $\mathrm{C} 26$ & $0.0228(6)$ & $0.0175(6)$ & $0.0288(7)$ & $0.0017(5)$ & $0.0085(5)$ & $-0.0025(5)$ \\
\hline $\mathrm{C} 27$ & $0.0255(7)$ & $0.0243(6)$ & $0.0288(7)$ & $-0.0048(5)$ & $0.0093(5)$ & $-0.0125(5)$ \\
\hline $\mathrm{C} 28$ & $0.0375(8)$ & $0.0377(8)$ & $0.0231(7)$ & $0.0042(7)$ & $-0.0066(6)$ & $-0.0143(6)$ \\
\hline $\mathrm{C} 29$ & $0.0323(7)$ & $0.0288(7)$ & $0.0183(6)$ & $0.0086(6)$ & $-0.0062(5)$ & $-0.0050(5)$ \\
\hline $\mathrm{C} 30$ & $0.0142(5)$ & $0.0166(5)$ & $0.0146(5)$ & -0.0010 & 0.0030 & -0.0014 \\
\hline $\mathrm{C} 31$ & $0.0189(6)$ & $0.0175(6)$ & $0.0215(6)$ & $0.0031(5)$ & $0.0046(5)$ & $0.0019(5)$ \\
\hline $\mathrm{C} 32$ & $0.0275(7)$ & $0.0154(6)$ & $0.0273(6)$ & $0.0013(5)$ & $0.0051(5)$ & $0.0048(5)$ \\
\hline C33 & $0.0218(6)$ & $0.0221(6)$ & $0.0189(6)$ & $-0.0056(5)$ & $0.0020(5)$ & $0.0043(5)$ \\
\hline
\end{tabular}




\begin{tabular}{|c|c|c|c|c|c|c|}
\hline $\mathrm{C} 34$ & $0.0155(5)$ & $0.0247(6)$ & $0.0176(6)$ & $-0.0018(5)$ & $0.0027(4)$ & $-0.0016(5)$ \\
\hline $\mathrm{C} 35$ & $0.0169(6)$ & $0.0154(5)$ & $0.0153(5)$ & $0.0010(4)$ & $0.0012(4)$ & -0.0010 \\
\hline $\mathrm{C} 36$ & $0.0157(5)$ & $0.0158(5)$ & $0.0101(5)$ & $0.0001(4)$ & $0.0002(4)$ & $-0.0002(4)$ \\
\hline $\mathrm{P} 3$ & $0.01686(14)$ & $0.01392(14)$ & $0.01790(14)$ & $0.00187(11)$ & $0.00514(11)$ & $-0.00059(11)$ \\
\hline $\mathrm{O} 3$ & $0.0249(4)$ & $0.0197(4)$ & $0.0215(4)$ & $0.0058(4)$ & $0.0082(4)$ & $-0.0020(3)$ \\
\hline C37 & $0.0198(6)$ & $0.0265(6)$ & $0.0257(6)$ & $-0.0007(5)$ & $0.0020(5)$ & $0.0058(5)$ \\
\hline $\mathrm{C} 38$ & $0.0247(7)$ & $0.0321(7)$ & $0.0380(8)$ & $-0.0025(6)$ & $0.0066(6)$ & $0.0114(6)$ \\
\hline C39 & $0.0210(6)$ & $0.0197(6)$ & $0.0507(9)$ & $-0.0035(5)$ & $0.0018(6)$ & $0.0018(6)$ \\
\hline $\mathrm{C} 40$ & $0.0296(7)$ & $0.0229(7)$ & $0.0390(8)$ & $-0.0050(6)$ & $-0.0060(6)$ & $-0.0052(6)$ \\
\hline C41 & $0.0332(7)$ & $0.0230(6)$ & $0.0245(6)$ & $-0.0046(6)$ & $0.0020(5)$ & $-0.0029(5)$ \\
\hline $\mathrm{C} 42$ & $0.0184(6)$ & $0.0124(5)$ & $0.0241(6)$ & $0.0016(4)$ & $0.0032(5)$ & $-0.0001(4)$ \\
\hline $\mathrm{C} 43$ & $0.0209(6)$ & $0.0217(6)$ & $0.0337(7)$ & $0.0023(5)$ & $0.0102(5)$ & $0.0037(5)$ \\
\hline $\mathrm{C} 44$ & $0.0231(6)$ & $0.0202(6)$ & $0.0472(8)$ & $0.0053(5)$ & $0.0085(6)$ & $0.0047(6)$ \\
\hline $\mathrm{C} 45$ & $0.0305(7)$ & $0.0203(6)$ & $0.0432(8)$ & $0.0004(6)$ & $0.0054(6)$ & $0.0114(6)$ \\
\hline $\mathrm{C} 46$ & $0.0315(7)$ & $0.0281(7)$ & $0.0339(7)$ & $-0.0005(6)$ & $0.0109(6)$ & $0.0091(6)$ \\
\hline $\mathrm{C} 47$ & $0.0231(6)$ & $0.0227(6)$ & $0.0273(6)$ & $0.0015(5)$ & $0.0083(5)$ & $0.0032(5)$ \\
\hline C48 & $0.0182(6)$ & $0.0162(6)$ & $0.0234(6)$ & $-0.0002(5)$ & $0.0039(5)$ & $0.0014(5)$ \\
\hline C49 & $0.0202(6)$ & $0.0230(6)$ & $0.0270(7)$ & $0.0017(5)$ & $0.0051(5)$ & $-0.0018(5)$ \\
\hline $\mathrm{C} 50$ & $0.0215(6)$ & $0.0308(7)$ & $0.0325(7)$ & $0.0011(5)$ & $-0.0021(5)$ & $0.0002(6)$ \\
\hline $\mathrm{C} 51$ & $0.0353(8)$ & $0.0301(7)$ & $0.0249(7)$ & $-0.0059(6)$ & $-0.0019(6)$ & $-0.0052(6)$ \\
\hline $\mathrm{C} 52$ & $0.0379(8)$ & $0.0267(7)$ & $0.0279(7)$ & $0.0008(6)$ & $0.0065(6)$ & $-0.0095(6)$ \\
\hline $\mathrm{C} 53$ & $0.0257(6)$ & $0.0234(6)$ & $0.0266(7)$ & $0.0039(5)$ & $0.0046(5)$ & $-0.0051(5)$ \\
\hline $\mathrm{C} 54$ & $0.0185(6)$ & $0.0165(5)$ & $0.0215(6)$ & $-0.0015(5)$ & $0.0040(5)$ & $-0.0014(5)$ \\
\hline P4 & $0.01651(14)$ & $0.01290(14)$ & $0.01749(14)$ & $0.00079(11)$ & $0.00375(11)$ & $-0.00068(11)$ \\
\hline $\mathrm{O} 4$ & $0.0241(4)$ & $0.0156(4)$ & $0.0196(4)$ & $0.0037(3)$ & $0.0063(3)$ & $-0.0012(3)$ \\
\hline C55 & $0.0279(7)$ & $0.0244(7)$ & $0.0328(7)$ & $-0.0063(5)$ & $0.0073(6)$ & $-0.0046(5)$ \\
\hline $\mathrm{C} 56$ & $0.0295(7)$ & $0.0259(7)$ & $0.0530(9)$ & $-0.0089(6)$ & $0.0084(7)$ & $-0.0013(7)$ \\
\hline $\mathrm{C} 57$ & $0.0253(7)$ & $0.0294(7)$ & $0.0562(10)$ & $0.0005(6)$ & $0.0170(7)$ & $0.0153(7)$ \\
\hline $\mathrm{C} 58$ & $0.0294(7)$ & $0.0373(8)$ & $0.0344(7)$ & $0.0095(6)$ & $0.0157(6)$ & $0.0123(6)$ \\
\hline C59 & $0.0236(6)$ & $0.0267(7)$ & $0.0251(6)$ & $0.0043(5)$ & $0.0071(5)$ & $0.0026(5)$ \\
\hline $\mathrm{C} 60$ & $0.0193(6)$ & $0.0143(5)$ & $0.0239(6)$ & $0.0025(5)$ & $0.0055(5)$ & $0.0036(5)$ \\
\hline C61 & $0.0236(6)$ & $0.0248(6)$ & $0.0268(7)$ & $0.0015(5)$ & $0.0015(5)$ & $-0.0020(5)$ \\
\hline C62 & $0.0287(7)$ & $0.0372(8)$ & $0.0288(7)$ & $0.0001(6)$ & $-0.0033(6)$ & $0.0010(6)$ \\
\hline C63 & $0.0282(7)$ & $0.0435(8)$ & $0.0216(6)$ & $-0.0135(6)$ & $0.0058(5)$ & $-0.0076(6)$ \\
\hline C64 & $0.0381(8)$ & $0.0325(8)$ & $0.0342(8)$ & $-0.0052(6)$ & $0.0061(6)$ & $-0.0163(6)$ \\
\hline C65 & $0.0340(7)$ & $0.0241(7)$ & $0.0330(7)$ & $0.0036(6)$ & $0.0001(6)$ & $-0.0085(6)$ \\
\hline C66 & $0.0173(6)$ & $0.0205(6)$ & $0.0202(6)$ & $-0.0024(5)$ & $0.0050(5)$ & $-0.0025(5)$ \\
\hline C67 & $0.0192(6)$ & $0.0202(6)$ & $0.0309(7)$ & $0.0021(5)$ & $0.0072(5)$ & $0.0029(5)$ \\
\hline C68 & $0.0197(6)$ & $0.0213(6)$ & $0.0414(8)$ & $0.0045(5)$ & $0.0056(6)$ & $0.0067(6)$ \\
\hline C69 & $0.0258(7)$ & $0.0227(6)$ & $0.0352(7)$ & $0.0012(5)$ & $0.0028(6)$ & $0.0117(6)$ \\
\hline $\mathrm{C} 70$ & $0.0260(7)$ & $0.0248(6)$ & $0.0282(7)$ & $-0.0024(5)$ & $0.0074(5)$ & $0.0056(5)$ \\
\hline C71 & $0.0189(6)$ & $0.0181(6)$ & $0.0255(6)$ & $-0.0010(5)$ & $0.0052(5)$ & $0.0006(5)$ \\
\hline C72 & $0.0164(6)$ & $0.0153(5)$ & $0.0226(6)$ & $-0.0020(4)$ & $0.0024(5)$ & $0.0009(5)$ \\
\hline
\end{tabular}

Geometric parameters $\left(A,{ }^{\circ}\right)$

\begin{tabular}{llll}
\hline $\mathrm{S} 1-\mathrm{C} 77$ & $1.7839(12)$ & $\mathrm{C} 20-\mathrm{H} 20$ & 0.9300 \\
$\mathrm{~S} 1-\mathrm{C} 80$ & $1.7764(12)$ & $\mathrm{C} 20-\mathrm{C} 21$ & $1.3866(18)$
\end{tabular}




\begin{tabular}{|c|c|c|c|}
\hline $\mathrm{O} 5-\mathrm{C} 79$ & $1.1978(17)$ & $\mathrm{C} 21-\mathrm{H} 21$ & 0.9300 \\
\hline $\mathrm{O} 6-\mathrm{H} 6 \mathrm{O}$ & $0.95(2)$ & $\mathrm{C} 21-\mathrm{C} 22$ & $1.3902(18)$ \\
\hline $\mathrm{O} 6-\mathrm{C} 79$ & $1.3043(15)$ & $\mathrm{C} 22-\mathrm{H} 22$ & 0.9300 \\
\hline $\mathrm{O} 7-\mathrm{C} 86$ & $1.2104(15)$ & $\mathrm{C} 22-\mathrm{C} 23$ & $1.3880(17)$ \\
\hline $\mathrm{O} 8-\mathrm{H} 8 \mathrm{O}$ & $0.90(2)$ & $\mathrm{C} 23-\mathrm{H} 23$ & 0.9300 \\
\hline $\mathrm{O} 8-\mathrm{C} 86$ & $1.3279(15)$ & $\mathrm{C} 23-\mathrm{C} 24$ & $1.4015(16)$ \\
\hline C73-H73 & 0.9300 & $\mathrm{C} 25-\mathrm{H} 25$ & 0.9300 \\
\hline $\mathrm{C} 73-\mathrm{C} 74$ & $1.3862(17)$ & $\mathrm{C} 25-\mathrm{C} 26$ & $1.3910(17)$ \\
\hline $\mathrm{C} 73-\mathrm{C} 78$ & $1.3942(17)$ & $\mathrm{C} 25-\mathrm{C} 30$ & $1.3914(17)$ \\
\hline C74-H74 & 0.9300 & $\mathrm{C} 26-\mathrm{H} 26$ & 0.9300 \\
\hline $\mathrm{C} 74-\mathrm{C} 75$ & $1.3866(19)$ & $\mathrm{C} 26-\mathrm{C} 27$ & $1.3799(19)$ \\
\hline C $75-\mathrm{H} 75$ & 0.9300 & $\mathrm{C} 27-\mathrm{H} 27$ & 0.9300 \\
\hline $\mathrm{C} 75-\mathrm{C} 76$ & $1.3854(19)$ & $\mathrm{C} 27-\mathrm{C} 28$ & $1.383(2)$ \\
\hline C76-H76 & 0.9300 & $\mathrm{C} 28-\mathrm{H} 28$ & 0.9300 \\
\hline $\mathrm{C} 76-\mathrm{C} 77$ & $1.3975(17)$ & $\mathrm{C} 28-\mathrm{C} 29$ & $1.3871(19)$ \\
\hline $\mathrm{C} 77-\mathrm{C} 78$ & $1.3996(16)$ & C29-H29 & 0.9300 \\
\hline $\mathrm{C} 78-\mathrm{C} 79$ & $1.4998(16)$ & $\mathrm{C} 29-\mathrm{C} 30$ & $1.3933(17)$ \\
\hline $\mathrm{C} 80-\mathrm{C} 81$ & $1.4024(16)$ & C31-H31 & 0.9300 \\
\hline $\mathrm{C} 80-\mathrm{C} 85$ & 1.4077 (17) & $\mathrm{C} 31-\mathrm{C} 32$ & $1.3898(18)$ \\
\hline C $81-\mathrm{H} 81$ & 0.9300 & $\mathrm{C} 31-\mathrm{C} 36$ & $1.3969(16)$ \\
\hline $\mathrm{C} 81-\mathrm{C} 82$ & $1.3847(19)$ & C $32-\mathrm{H} 32$ & 0.9300 \\
\hline $\mathrm{C} 82-\mathrm{H} 82$ & 0.9300 & $\mathrm{C} 32-\mathrm{C} 33$ & $1.3857(19)$ \\
\hline $\mathrm{C} 82-\mathrm{C} 83$ & $1.388(2)$ & $\mathrm{C} 33-\mathrm{H} 33$ & 0.9300 \\
\hline C83-H83 & 0.9300 & C $33-\mathrm{C} 34$ & $1.3883(18)$ \\
\hline $\mathrm{C} 83-\mathrm{C} 84$ & $1.3826(18)$ & C34-H34 & 0.9300 \\
\hline $\mathrm{C} 84-\mathrm{H} 84$ & 0.9300 & $\mathrm{C} 34-\mathrm{C} 35$ & $1.3907(17)$ \\
\hline C84-C85 & $1.4004(17)$ & C35-H35 & 0.9300 \\
\hline $\mathrm{C} 85-\mathrm{C} 86$ & $1.4921(16)$ & $\mathrm{C} 35-\mathrm{C} 36$ & $1.3983(16)$ \\
\hline $\mathrm{S} 2-\mathrm{C} 92$ & $1.7760(12)$ & $\mathrm{P} 3-\mathrm{O} 3$ & $1.4991(9)$ \\
\hline $\mathrm{S} 2-\mathrm{C} 94$ & $1.7863(12)$ & $\mathrm{P} 3-\mathrm{C} 42$ & $1.8004(13)$ \\
\hline $\mathrm{O} 9-\mathrm{C} 93$ & $1.2147(15)$ & P3-C48 & $1.8001(12)$ \\
\hline $\mathrm{O} 10-\mathrm{H} 10 \mathrm{O}$ & $0.91(2)$ & $\mathrm{P} 3-\mathrm{C} 54$ & $1.7989(13)$ \\
\hline $\mathrm{O} 10-\mathrm{C} 93$ & $1.3309(14)$ & C37-H37 & 0.9300 \\
\hline $\mathrm{O} 11-\mathrm{C} 100$ & $1.2075(16)$ & $\mathrm{C} 37-\mathrm{C} 38$ & $1.3912(19)$ \\
\hline $\mathrm{O} 12-\mathrm{H} 12 \mathrm{O}$ & $0.89(2)$ & $\mathrm{C} 37-\mathrm{C} 42$ & $1.3915(17)$ \\
\hline $\mathrm{O} 12-\mathrm{C} 100$ & $1.3126(15)$ & C $38-\mathrm{H} 38$ & 0.9300 \\
\hline C87-H87 & 0.9300 & $\mathrm{C} 38-\mathrm{C} 39$ & $1.380(2)$ \\
\hline $\mathrm{C} 87-\mathrm{C} 88$ & $1.3842(17)$ & C39-H39 & 0.9300 \\
\hline C87-C92 & $1.4042(16)$ & $\mathrm{C} 39-\mathrm{C} 40$ & $1.380(2)$ \\
\hline C88-H88 & 0.9300 & $\mathrm{C} 40-\mathrm{H} 40$ & 0.9300 \\
\hline $\mathrm{C} 88-\mathrm{C} 89$ & $1.3887(19)$ & $\mathrm{C} 40-\mathrm{C} 41$ & $1.385(2)$ \\
\hline C89-H89 & 0.9300 & $\mathrm{C} 41-\mathrm{H} 41$ & 0.9300 \\
\hline $\mathrm{C} 89-\mathrm{C} 90$ & $1.3853(18)$ & $\mathrm{C} 41-\mathrm{C} 42$ & $1.3949(18)$ \\
\hline $\mathrm{C} 90-\mathrm{H} 90$ & 0.9300 & $\mathrm{C} 43-\mathrm{H} 43$ & 0.9300 \\
\hline $\mathrm{C} 90-\mathrm{C} 91$ & $1.4008(16)$ & $\mathrm{C} 43-\mathrm{C} 44$ & 1.3865 (19) \\
\hline C91-C92 & $1.4087(16)$ & $\mathrm{C} 43-\mathrm{C} 48$ & $1.3973(17)$ \\
\hline C91-C93 & $1.4900(16)$ & $\mathrm{C} 44-\mathrm{H} 44$ & 0.9300 \\
\hline C94-C95 & $1.3980(17)$ & $\mathrm{C} 44-\mathrm{C} 45$ & $1.388(2)$ \\
\hline
\end{tabular}




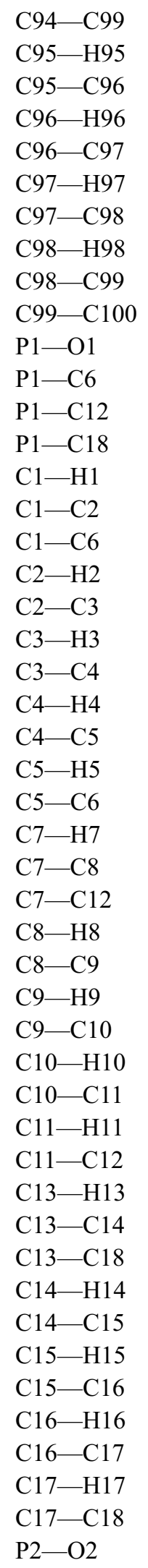

1.4031 (17)

0.9300

1.3879 (18)

0.9300

1.3876 (19)

0.9300

1.3856 (18)

0.9300

$1.3979(16)$

$1.4997(17)$

1.5018 (8)

$1.7961(11)$

$1.8003(12)$

1.7994 (12)

0.9300

$1.3952(16)$

1.3909 (16)

0.9300

1.3874 (18)

0.9300

1.3890 (18)

0.9300

1.3868 (17)

0.9300

1.4007 (16)

0.9300

1.3915 (17)

1.3920 (17)

0.9300

$1.379(2)$

0.9300

1.381 (2)

0.9300

1.387 (2)

0.9300

$1.3941(17)$

0.9300

1.3901 (17)

1.3979 (16)

0.9300

1.3902 (18)

0.9300

1.3854 (19)

0.9300

$1.3902(17)$

0.9300

1.3956 (16)

$1.5014(8)$

\section{C45-H45}

$\mathrm{C} 45-\mathrm{C} 46$

$\mathrm{C} 46-\mathrm{H} 46$

C46-C47

C47-H47

C47-C48

C49-H49

C49-C50

C49-C54

C $50-\mathrm{H} 50$

C50-C51

C51-H51

C $51-\mathrm{C} 52$

C52-H52

C $52-\mathrm{C} 53$

C $53-\mathrm{H} 53$

C53-C54

P4-O4

P4-C60

P4-C66

$\mathrm{P} 4-\mathrm{C} 72$

C55-H55

C55-C56

C55-C60

C56-H56

C56-C57

C57-H57

C57-C58

C $58-\mathrm{H} 58$

C58-C59

C59-H59

C59-C60

C61-H61

C61-C62

C61-C66

C62-H62

C62-C63

C63-H63

C63-C64

C64-H64

C64-C65

C65-H65

C65-C66

C67-H67

C67-C68

C67-C72

C68-H68

C68-C69

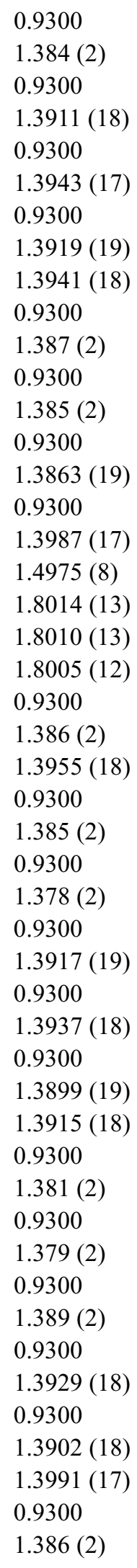




\begin{tabular}{|c|c|c|c|}
\hline $\mathrm{P} 2-\mathrm{C} 24$ & $1.7997(11)$ & C69-H69 & 0.9300 \\
\hline $\mathrm{P} 2-\mathrm{C} 30$ & $1.7998(12)$ & $\mathrm{C} 69-\mathrm{C} 70$ & $1.389(2)$ \\
\hline $\mathrm{P} 2-\mathrm{C} 36$ & $1.7980(12)$ & $\mathrm{C} 70-\mathrm{H} 70$ & 0.9300 \\
\hline C19-H19 & 0.9300 & $\mathrm{C} 70-\mathrm{C} 71$ & $1.3889(18)$ \\
\hline $\mathrm{C} 19-\mathrm{C} 20$ & $1.3956(16)$ & $\mathrm{C} 71-\mathrm{H} 71$ & 0.9300 \\
\hline $\mathrm{C} 19-\mathrm{C} 24$ & $1.3927(16)$ & $\mathrm{C} 71-\mathrm{C} 72$ & $1.3990(17)$ \\
\hline $\mathrm{C} 80-\mathrm{S} 1-\mathrm{C} 77$ & $101.78(6)$ & $\mathrm{C} 21-\mathrm{C} 22-\mathrm{H} 22$ & 120.0 \\
\hline $\mathrm{C} 79-\mathrm{O} 6-\mathrm{H} 6 \mathrm{O}$ & $109.8(14)$ & $\mathrm{C} 23-\mathrm{C} 22-\mathrm{C} 21$ & $120.02(11)$ \\
\hline $\mathrm{C} 86-\mathrm{O} 8-\mathrm{H} 8 \mathrm{O}$ & $111.7(14)$ & $\mathrm{C} 23-\mathrm{C} 22-\mathrm{H} 22$ & 120.0 \\
\hline $\mathrm{C} 74-\mathrm{C} 73-\mathrm{H} 73$ & 119.7 & $\mathrm{C} 22-\mathrm{C} 23-\mathrm{H} 23$ & 120.0 \\
\hline $\mathrm{C} 74-\mathrm{C} 73-\mathrm{C} 78$ & $120.70(11)$ & $\mathrm{C} 22-\mathrm{C} 23-\mathrm{C} 24$ & $119.91(11)$ \\
\hline $\mathrm{C} 78-\mathrm{C} 73-\mathrm{H} 73$ & 119.7 & $\mathrm{C} 24-\mathrm{C} 23-\mathrm{H} 23$ & 120.0 \\
\hline $\mathrm{C} 73-\mathrm{C} 74-\mathrm{H} 74$ & 120.2 & $\mathrm{C} 19-\mathrm{C} 24-\mathrm{P} 2$ & $122.36(9)$ \\
\hline $\mathrm{C} 73-\mathrm{C} 74-\mathrm{C} 75$ & $119.62(11)$ & $\mathrm{C} 19-\mathrm{C} 24-\mathrm{C} 23$ & $119.73(10)$ \\
\hline C $75-\mathrm{C} 74-\mathrm{H} 74$ & 120.2 & $\mathrm{C} 23-\mathrm{C} 24-\mathrm{P} 2$ & $117.90(9)$ \\
\hline $\mathrm{C} 74-\mathrm{C} 75-\mathrm{H} 75$ & 119.9 & $\mathrm{C} 26-\mathrm{C} 25-\mathrm{H} 25$ & 119.9 \\
\hline $\mathrm{C} 76-\mathrm{C} 75-\mathrm{C} 74$ & $120.21(11)$ & $\mathrm{C} 26-\mathrm{C} 25-\mathrm{C} 30$ & $120.21(11)$ \\
\hline C76-C75-H75 & 119.9 & $\mathrm{C} 30-\mathrm{C} 25-\mathrm{H} 25$ & 119.9 \\
\hline $\mathrm{C} 75-\mathrm{C} 76-\mathrm{H} 76$ & 119.6 & $\mathrm{C} 25-\mathrm{C} 26-\mathrm{H} 26$ & 119.8 \\
\hline $\mathrm{C} 75-\mathrm{C} 76-\mathrm{C} 77$ & $120.71(12)$ & $\mathrm{C} 27-\mathrm{C} 26-\mathrm{C} 25$ & $120.31(12)$ \\
\hline $\mathrm{C} 77-\mathrm{C} 76-\mathrm{H} 76$ & 119.6 & $\mathrm{C} 27-\mathrm{C} 26-\mathrm{H} 26$ & 119.8 \\
\hline $\mathrm{C} 76-\mathrm{C} 77-\mathrm{S} 1$ & $119.72(9)$ & $\mathrm{C} 26-\mathrm{C} 27-\mathrm{H} 27$ & 120.1 \\
\hline $\mathrm{C} 76-\mathrm{C} 77-\mathrm{C} 78$ & $118.98(11)$ & $\mathrm{C} 26-\mathrm{C} 27-\mathrm{C} 28$ & $119.79(12)$ \\
\hline $\mathrm{C} 78-\mathrm{C} 77-\mathrm{S} 1$ & $121.28(9)$ & $\mathrm{C} 28-\mathrm{C} 27-\mathrm{H} 27$ & 120.1 \\
\hline $\mathrm{C} 73-\mathrm{C} 78-\mathrm{C} 77$ & $119.77(11)$ & $\mathrm{C} 27-\mathrm{C} 28-\mathrm{H} 28$ & 119.8 \\
\hline $\mathrm{C} 73-\mathrm{C} 78-\mathrm{C} 79$ & $116.79(11)$ & $\mathrm{C} 27-\mathrm{C} 28-\mathrm{C} 29$ & $120.33(13)$ \\
\hline $\mathrm{C} 77-\mathrm{C} 78-\mathrm{C} 79$ & $123.40(11)$ & $\mathrm{C} 29-\mathrm{C} 28-\mathrm{H} 28$ & 119.8 \\
\hline $\mathrm{O} 5-\mathrm{C} 79-\mathrm{O} 6$ & $123.45(12)$ & $\mathrm{C} 28-\mathrm{C} 29-\mathrm{H} 29$ & 119.9 \\
\hline $\mathrm{O} 5-\mathrm{C} 79-\mathrm{C} 78$ & $121.67(12)$ & $\mathrm{C} 28-\mathrm{C} 29-\mathrm{C} 30$ & $120.27(13)$ \\
\hline $\mathrm{O} 6-\mathrm{C} 79-\mathrm{C} 78$ & $114.76(11)$ & $\mathrm{C} 30-\mathrm{C} 29-\mathrm{H} 29$ & 119.9 \\
\hline $\mathrm{C} 81-\mathrm{C} 80-\mathrm{S} 1$ & $122.19(9)$ & $\mathrm{C} 25-\mathrm{C} 30-\mathrm{P} 2$ & $123.58(9)$ \\
\hline $\mathrm{C} 81-\mathrm{C} 80-\mathrm{C} 85$ & $117.98(11)$ & $\mathrm{C} 25-\mathrm{C} 30-\mathrm{C} 29$ & $119.09(11)$ \\
\hline $\mathrm{C} 85-\mathrm{C} 80-\mathrm{S} 1$ & $119.81(9)$ & $\mathrm{C} 29-\mathrm{C} 30-\mathrm{P} 2$ & $117.33(9)$ \\
\hline $\mathrm{C} 80-\mathrm{C} 81-\mathrm{H} 81$ & 119.5 & $\mathrm{C} 32-\mathrm{C} 31-\mathrm{H} 31$ & 120.2 \\
\hline $\mathrm{C} 82-\mathrm{C} 81-\mathrm{C} 80$ & $121.10(12)$ & $\mathrm{C} 32-\mathrm{C} 31-\mathrm{C} 36$ & $119.67(11)$ \\
\hline $\mathrm{C} 82-\mathrm{C} 81-\mathrm{H} 81$ & 119.5 & $\mathrm{C} 36-\mathrm{C} 31-\mathrm{H} 31$ & 120.2 \\
\hline $\mathrm{C} 81-\mathrm{C} 82-\mathrm{H} 82$ & 119.6 & $\mathrm{C} 31-\mathrm{C} 32-\mathrm{H} 32$ & 119.8 \\
\hline $\mathrm{C} 81-\mathrm{C} 82-\mathrm{C} 83$ & $120.85(12)$ & $\mathrm{C} 33-\mathrm{C} 32-\mathrm{C} 31$ & $120.40(12)$ \\
\hline $\mathrm{C} 83-\mathrm{C} 82-\mathrm{H} 82$ & 119.6 & $\mathrm{C} 33-\mathrm{C} 32-\mathrm{H} 32$ & 119.8 \\
\hline $\mathrm{C} 82-\mathrm{C} 83-\mathrm{H} 83$ & 120.6 & $\mathrm{C} 32-\mathrm{C} 33-\mathrm{H} 33$ & 119.9 \\
\hline $\mathrm{C} 84-\mathrm{C} 83-\mathrm{C} 82$ & $118.84(12)$ & $\mathrm{C} 32-\mathrm{C} 33-\mathrm{C} 34$ & $120.29(11)$ \\
\hline $\mathrm{C} 84-\mathrm{C} 83-\mathrm{H} 83$ & 120.6 & $\mathrm{C} 34-\mathrm{C} 33-\mathrm{H} 33$ & 119.9 \\
\hline $\mathrm{C} 83-\mathrm{C} 84-\mathrm{H} 84$ & 119.4 & $\mathrm{C} 33-\mathrm{C} 34-\mathrm{H} 34$ & 120.1 \\
\hline $\mathrm{C} 83-\mathrm{C} 84-\mathrm{C} 85$ & $121.26(12)$ & $\mathrm{C} 33-\mathrm{C} 34-\mathrm{C} 35$ & $119.76(11)$ \\
\hline $\mathrm{C} 85-\mathrm{C} 84-\mathrm{H} 84$ & 119.4 & $\mathrm{C} 35-\mathrm{C} 34-\mathrm{H} 34$ & 120.1 \\
\hline $\mathrm{C} 80-\mathrm{C} 85-\mathrm{C} 86$ & $121.64(11)$ & $\mathrm{C} 34-\mathrm{C} 35-\mathrm{H} 35$ & 119.9 \\
\hline $\mathrm{C} 84-\mathrm{C} 85-\mathrm{C} 80$ & 119.94 (11) & $\mathrm{C} 34-\mathrm{C} 35-\mathrm{C} 36$ & $120.18(11)$ \\
\hline
\end{tabular}




\begin{tabular}{|c|c|c|c|}
\hline $\mathrm{C} 84-\mathrm{C} 85-\mathrm{C} 86$ & $118.41(11)$ & $\mathrm{C} 36-\mathrm{C} 35-\mathrm{H} 35$ & 119.9 \\
\hline $\mathrm{O} 7-\mathrm{C} 86-\mathrm{O} 8$ & $124.24(11)$ & $\mathrm{C} 31-\mathrm{C} 36-\mathrm{P} 2$ & $117.85(9)$ \\
\hline $\mathrm{O} 7-\mathrm{C} 86-\mathrm{C} 85$ & $123.93(11)$ & $\mathrm{C} 31-\mathrm{C} 36-\mathrm{C} 35$ & $119.68(11)$ \\
\hline $\mathrm{O} 8-\mathrm{C} 86-\mathrm{C} 85$ & $111.83(10)$ & $\mathrm{C} 35-\mathrm{C} 36-\mathrm{P} 2$ & $122.46(9)$ \\
\hline $\mathrm{C} 92-\mathrm{S} 2-\mathrm{C} 94$ & $100.52(5)$ & $\mathrm{O} 3-\mathrm{P} 3-\mathrm{C} 42$ & $112.18(5)$ \\
\hline $\mathrm{C} 93-\mathrm{O} 10-\mathrm{H} 10 \mathrm{O}$ & $110.6(14)$ & $\mathrm{O} 3-\mathrm{P} 3-\mathrm{C} 48$ & $111.75(5)$ \\
\hline $\mathrm{C} 100-\mathrm{O} 12-\mathrm{H} 12 \mathrm{O}$ & $111.0(12)$ & $\mathrm{O} 3-\mathrm{P} 3-\mathrm{C} 54$ & $110.01(6)$ \\
\hline $\mathrm{C} 88-\mathrm{C} 87-\mathrm{H} 87$ & 119.4 & $\mathrm{C} 48-\mathrm{P} 3-\mathrm{C} 42$ & $105.87(6)$ \\
\hline C88-C87-C92 & $121.16(11)$ & $\mathrm{C} 54-\mathrm{P} 3-\mathrm{C} 42$ & $107.61(6)$ \\
\hline C92-C $87-\mathrm{H} 87$ & 119.4 & $\mathrm{C} 54-\mathrm{P} 3-\mathrm{C} 48$ & $109.24(6)$ \\
\hline $\mathrm{C} 87-\mathrm{C} 88-\mathrm{H} 88$ & 119.7 & $\mathrm{C} 38-\mathrm{C} 37-\mathrm{H} 37$ & 120.0 \\
\hline $\mathrm{C} 87-\mathrm{C} 88-\mathrm{C} 89$ & $120.59(11)$ & $\mathrm{C} 38-\mathrm{C} 37-\mathrm{C} 42$ & $120.05(13)$ \\
\hline C $89-\mathrm{C} 88-\mathrm{H} 88$ & 119.7 & $\mathrm{C} 42-\mathrm{C} 37-\mathrm{H} 37$ & 120.0 \\
\hline $\mathrm{C} 88-\mathrm{C} 89-\mathrm{H} 89$ & 120.5 & $\mathrm{C} 37-\mathrm{C} 38-\mathrm{H} 38$ & 119.8 \\
\hline $\mathrm{C} 90-\mathrm{C} 89-\mathrm{C} 88$ & $119.06(12)$ & $\mathrm{C} 39-\mathrm{C} 38-\mathrm{C} 37$ & $120.41(13)$ \\
\hline $\mathrm{C} 90-\mathrm{C} 89-\mathrm{H} 89$ & 120.5 & $\mathrm{C} 39-\mathrm{C} 38-\mathrm{H} 38$ & 119.8 \\
\hline $\mathrm{C} 89-\mathrm{C} 90-\mathrm{H} 90$ & 119.4 & C38-C39-H39 & 120.1 \\
\hline $\mathrm{C} 89-\mathrm{C} 90-\mathrm{C} 91$ & $121.30(12)$ & C $38-\mathrm{C} 39-\mathrm{C} 40$ & $119.79(13)$ \\
\hline $\mathrm{C} 91-\mathrm{C} 90-\mathrm{H} 90$ & 119.4 & $\mathrm{C} 40-\mathrm{C} 39-\mathrm{H} 39$ & 120.1 \\
\hline $\mathrm{C} 90-\mathrm{C} 91-\mathrm{C} 92$ & $119.64(11)$ & $\mathrm{C} 39-\mathrm{C} 40-\mathrm{H} 40$ & 119.8 \\
\hline $\mathrm{C} 90-\mathrm{C} 91-\mathrm{C} 93$ & $118.82(11)$ & $\mathrm{C} 39-\mathrm{C} 40-\mathrm{C} 41$ & $120.39(13)$ \\
\hline C92-C91-C93 & $121.50(10)$ & $\mathrm{C} 41-\mathrm{C} 40-\mathrm{H} 40$ & 119.8 \\
\hline $\mathrm{C} 87-\mathrm{C} 92-\mathrm{S} 2$ & $121.33(9)$ & $\mathrm{C} 40-\mathrm{C} 41-\mathrm{H} 41$ & 119.9 \\
\hline $\mathrm{C} 87-\mathrm{C} 92-\mathrm{C} 91$ & $118.24(11)$ & $\mathrm{C} 40-\mathrm{C} 41-\mathrm{C} 42$ & $120.28(13)$ \\
\hline $\mathrm{C} 91-\mathrm{C} 92-\mathrm{S} 2$ & $120.40(9)$ & $\mathrm{C} 42-\mathrm{C} 41-\mathrm{H} 41$ & 119.9 \\
\hline $\mathrm{O} 9-\mathrm{C} 93-\mathrm{O} 10$ & $123.83(11)$ & $\mathrm{C} 37-\mathrm{C} 42-\mathrm{P} 3$ & $123.98(10)$ \\
\hline $\mathrm{O} 9-\mathrm{C} 93-\mathrm{C} 91$ & $123.56(11)$ & $\mathrm{C} 37-\mathrm{C} 42-\mathrm{C} 41$ & $119.08(12)$ \\
\hline $\mathrm{O} 10-\mathrm{C} 93-\mathrm{C} 91$ & $112.61(10)$ & $\mathrm{C} 41-\mathrm{C} 42-\mathrm{P} 3$ & $116.74(10)$ \\
\hline C95-C94-S2 & $118.49(9)$ & $\mathrm{C} 44-\mathrm{C} 43-\mathrm{H} 43$ & 119.8 \\
\hline C95-C94-C99 & $119.21(11)$ & $\mathrm{C} 44-\mathrm{C} 43-\mathrm{C} 48$ & $120.32(12)$ \\
\hline $\mathrm{C} 99-\mathrm{C} 94-\mathrm{S} 2$ & $122.30(9)$ & $\mathrm{C} 48-\mathrm{C} 43-\mathrm{H} 43$ & 119.8 \\
\hline C94-C95-H95 & 119.6 & $\mathrm{C} 43-\mathrm{C} 44-\mathrm{H} 44$ & 120.1 \\
\hline C96-C95-C94 & $120.76(12)$ & $\mathrm{C} 43-\mathrm{C} 44-\mathrm{C} 45$ & $119.82(13)$ \\
\hline $\mathrm{C} 96-\mathrm{C} 95-\mathrm{H} 95$ & 119.6 & $\mathrm{C} 45-\mathrm{C} 44-\mathrm{H} 44$ & 120.1 \\
\hline $\mathrm{C} 95-\mathrm{C} 96-\mathrm{H} 96$ & 120.0 & $\mathrm{C} 44-\mathrm{C} 45-\mathrm{H} 45$ & 119.9 \\
\hline C97-C96-C95 & $120.05(12)$ & $\mathrm{C} 46-\mathrm{C} 45-\mathrm{C} 44$ & $120.25(13)$ \\
\hline C97-C96-H96 & 120.0 & $\mathrm{C} 46-\mathrm{C} 45-\mathrm{H} 45$ & 119.9 \\
\hline C96-C97-H97 & 120.1 & $\mathrm{C} 45-\mathrm{C} 46-\mathrm{H} 46$ & 119.9 \\
\hline $\mathrm{C} 98-\mathrm{C} 97-\mathrm{C} 96$ & $119.71(12)$ & $\mathrm{C} 45-\mathrm{C} 46-\mathrm{C} 47$ & $120.28(13)$ \\
\hline C98-C97-H97 & 120.1 & $\mathrm{C} 47-\mathrm{C} 46-\mathrm{H} 46$ & 119.9 \\
\hline C97-C98-H98 & 119.5 & $\mathrm{C} 46-\mathrm{C} 47-\mathrm{H} 47$ & 120.1 \\
\hline C97-C98-C99 & $120.98(12)$ & $\mathrm{C} 46-\mathrm{C} 47-\mathrm{C} 48$ & $119.82(12)$ \\
\hline C99-C98-H98 & 119.5 & $\mathrm{C} 48-\mathrm{C} 47-\mathrm{H} 47$ & 120.1 \\
\hline C94-C99-C100 & $124.32(11)$ & $\mathrm{C} 43-\mathrm{C} 48-\mathrm{P} 3$ & $121.55(10)$ \\
\hline C98-C99-C94 & $119.28(11)$ & $\mathrm{C} 47-\mathrm{C} 48-\mathrm{P} 3$ & $118.94(9)$ \\
\hline $\mathrm{C} 98-\mathrm{C} 99-\mathrm{C} 100$ & $116.38(11)$ & $\mathrm{C} 47-\mathrm{C} 48-\mathrm{C} 43$ & $119.50(12)$ \\
\hline $\mathrm{O} 11-\mathrm{C} 100-\mathrm{O} 12$ & $123.80(12)$ & $\mathrm{C} 50-\mathrm{C} 49-\mathrm{H} 49$ & 120.0 \\
\hline $\mathrm{O} 11-\mathrm{C} 100-\mathrm{C} 99$ & $121.95(11)$ & $\mathrm{C} 50-\mathrm{C} 49-\mathrm{C} 54$ & $120.05(12)$ \\
\hline
\end{tabular}




\begin{tabular}{|c|c|c|c|}
\hline $\mathrm{O} 12-\mathrm{C} 100-\mathrm{C} 99$ & $114.18(10)$ & $\mathrm{C} 54-\mathrm{C} 49-\mathrm{H} 49$ & 120.0 \\
\hline $\mathrm{O} 1-\mathrm{P} 1-\mathrm{C} 6$ & $112.35(5)$ & $\mathrm{C} 49-\mathrm{C} 50-\mathrm{H} 50$ & 120.0 \\
\hline $\mathrm{O} 1-\mathrm{P} 1-\mathrm{C} 12$ & $111.32(5)$ & $\mathrm{C} 51-\mathrm{C} 50-\mathrm{C} 49$ & $120.01(13)$ \\
\hline $\mathrm{O} 1-\mathrm{P} 1-\mathrm{C} 18$ & $111.73(5)$ & $\mathrm{C} 51-\mathrm{C} 50-\mathrm{H} 50$ & 120.0 \\
\hline $\mathrm{C} 6-\mathrm{P} 1-\mathrm{C} 12$ & $106.40(5)$ & $\mathrm{C} 50-\mathrm{C} 51-\mathrm{H} 51$ & 119.9 \\
\hline $\mathrm{C} 6-\mathrm{P} 1-\mathrm{C} 18$ & $107.57(5)$ & $\mathrm{C} 52-\mathrm{C} 51-\mathrm{C} 50$ & $120.25(13)$ \\
\hline $\mathrm{C} 18-\mathrm{P} 1-\mathrm{C} 12$ & $107.14(5)$ & $\mathrm{C} 52-\mathrm{C} 51-\mathrm{H} 51$ & 119.9 \\
\hline $\mathrm{C} 2-\mathrm{C} 1-\mathrm{H} 1$ & 120.0 & $\mathrm{C} 51-\mathrm{C} 52-\mathrm{H} 52$ & 120.0 \\
\hline $\mathrm{C} 6-\mathrm{C} 1-\mathrm{H} 1$ & 120.0 & $\mathrm{C} 51-\mathrm{C} 52-\mathrm{C} 53$ & 120.08 \\
\hline $\mathrm{C} 6-\mathrm{C} 1-\mathrm{C} 2$ & $120.03(11)$ & $\mathrm{C} 53-\mathrm{C} 52-\mathrm{H} 52$ & 120.0 \\
\hline $\mathrm{C} 1-\mathrm{C} 2-\mathrm{H} 2$ & 120.1 & $\mathrm{C} 52-\mathrm{C} 53-\mathrm{H} 53$ & 119.9 \\
\hline $\mathrm{C} 3-\mathrm{C} 2-\mathrm{C} 1$ & $119.77(11)$ & $\mathrm{C} 52-\mathrm{C} 53-\mathrm{C} 54$ & $120.19(13)$ \\
\hline $\mathrm{C} 3-\mathrm{C} 2-\mathrm{H} 2$ & 120.1 & $\mathrm{C} 54-\mathrm{C} 53-\mathrm{H} 53$ & 119.9 \\
\hline $\mathrm{C} 2-\mathrm{C} 3-\mathrm{H} 3$ & 119.8 & $\mathrm{C} 49-\mathrm{C} 54-\mathrm{P} 3$ & $118.37(9)$ \\
\hline $\mathrm{C} 2-\mathrm{C} 3-\mathrm{C} 4$ & $120.38(11)$ & $\mathrm{C} 49-\mathrm{C} 54-\mathrm{C} 53$ & $119.40(12)$ \\
\hline $\mathrm{C} 4-\mathrm{C} 3-\mathrm{H} 3$ & 119.8 & $\mathrm{C} 53-\mathrm{C} 54-\mathrm{P} 3$ & $122.23(10)$ \\
\hline $\mathrm{C} 3-\mathrm{C} 4-\mathrm{H} 4$ & 119.9 & $\mathrm{O} 4-\mathrm{P} 4-\mathrm{C} 60$ & $111.07(5)$ \\
\hline $\mathrm{C} 5-\mathrm{C} 4-\mathrm{C} 3$ & $120.12(11)$ & $\mathrm{O} 4-\mathrm{P} 4-\mathrm{C} 66$ & $111.08(5)$ \\
\hline $\mathrm{C} 5-\mathrm{C} 4-\mathrm{H} 4$ & 119.9 & $\mathrm{O} 4-\mathrm{P} 4-\mathrm{C} 72$ & $111.95(5)$ \\
\hline $\mathrm{C} 4-\mathrm{C} 5-\mathrm{H} 5$ & 120.1 & $\mathrm{C} 66-\mathrm{P} 4-\mathrm{C} 60$ & $105.35(6)$ \\
\hline $\mathrm{C} 4-\mathrm{C} 5-\mathrm{C} 6$ & $119.81(11)$ & $\mathrm{C} 72-\mathrm{P} 4-\mathrm{C} 60$ & $107.95(6)$ \\
\hline $\mathrm{C} 6-\mathrm{C} 5-\mathrm{H} 5$ & 120.1 & $\mathrm{C} 72-\mathrm{P} 4-\mathrm{C} 66$ & $109.19(6)$ \\
\hline $\mathrm{C} 1-\mathrm{C} 6-\mathrm{P} 1$ & $122.24(9)$ & C56-C55-H55 & 119.9 \\
\hline $\mathrm{C} 1-\mathrm{C} 6-\mathrm{C} 5$ & $119.86(10)$ & $\mathrm{C} 56-\mathrm{C} 55-\mathrm{C} 60$ & $120.19(13)$ \\
\hline $\mathrm{C} 5-\mathrm{C} 6-\mathrm{P} 1$ & $117.90(9)$ & $\mathrm{C} 60-\mathrm{C} 55-\mathrm{H} 55$ & 119.9 \\
\hline $\mathrm{C} 8-\mathrm{C} 7-\mathrm{H} 7$ & 119.9 & $\mathrm{C} 55-\mathrm{C} 56-\mathrm{H} 56$ & 120.0 \\
\hline $\mathrm{C} 8-\mathrm{C} 7-\mathrm{C} 12$ & $120.14(12)$ & $\mathrm{C} 57-\mathrm{C} 56-\mathrm{C} 55$ & $119.95(14)$ \\
\hline $\mathrm{C} 12-\mathrm{C} 7-\mathrm{H} 7$ & 119.9 & $\mathrm{C} 57-\mathrm{C} 56-\mathrm{H} 56$ & 120.0 \\
\hline $\mathrm{C} 7-\mathrm{C} 8-\mathrm{H} 8$ & 119.9 & $\mathrm{C} 56-\mathrm{C} 57-\mathrm{H} 57$ & 119.8 \\
\hline $\mathrm{C} 9-\mathrm{C} 8-\mathrm{C} 7$ & $120.28(13)$ & $\mathrm{C} 58-\mathrm{C} 57-\mathrm{C} 56$ & $120.41(13)$ \\
\hline $\mathrm{C} 9-\mathrm{C} 8-\mathrm{H} 8$ & 119.9 & $\mathrm{C} 58-\mathrm{C} 57-\mathrm{H} 57$ & 119.8 \\
\hline $\mathrm{C} 8-\mathrm{C} 9-\mathrm{H} 9$ & 120.1 & $\mathrm{C} 57-\mathrm{C} 58-\mathrm{H} 58$ & 120.0 \\
\hline $\mathrm{C} 8-\mathrm{C} 9-\mathrm{C} 10$ & $119.85(12)$ & $\mathrm{C} 57-\mathrm{C} 58-\mathrm{C} 59$ & $120.05(14)$ \\
\hline $\mathrm{C} 10-\mathrm{C} 9-\mathrm{H} 9$ & 120.1 & $\mathrm{C} 59-\mathrm{C} 58-\mathrm{H} 58$ & 120.0 \\
\hline $\mathrm{C} 9-\mathrm{C} 10-\mathrm{H} 10$ & 119.8 & $\mathrm{C} 58-\mathrm{C} 59-\mathrm{H} 59$ & 120.0 \\
\hline $\mathrm{C} 9-\mathrm{C} 10-\mathrm{C} 11$ & $120.47(13)$ & $\mathrm{C} 58-\mathrm{C} 59-\mathrm{C} 60$ & $120.01(13)$ \\
\hline $\mathrm{C} 11-\mathrm{C} 10-\mathrm{H} 10$ & 119.8 & $\mathrm{C} 60-\mathrm{C} 59-\mathrm{H} 59$ & 120.0 \\
\hline $\mathrm{C} 10-\mathrm{C} 11-\mathrm{H} 11$ & 120.0 & $\mathrm{C} 55-\mathrm{C} 60-\mathrm{P} 4$ & $117.07(10)$ \\
\hline $\mathrm{C} 10-\mathrm{C} 11-\mathrm{C} 12$ & $120.08(13)$ & $\mathrm{C} 59-\mathrm{C} 60-\mathrm{P} 4$ & $123.46(10)$ \\
\hline $\mathrm{C} 12-\mathrm{C} 11-\mathrm{H} 11$ & 120.0 & $\mathrm{C} 59-\mathrm{C} 60-\mathrm{C} 55$ & $119.39(12)$ \\
\hline $\mathrm{C} 7-\mathrm{C} 12-\mathrm{P} 1$ & $123.65(9)$ & C62-C61-H61 & 119.9 \\
\hline $\mathrm{C} 7-\mathrm{C} 12-\mathrm{C} 11$ & $119.17(11)$ & C62-C61-C66 & $120.23(13)$ \\
\hline $\mathrm{C} 11-\mathrm{C} 12-\mathrm{P} 1$ & $117.18(10)$ & $\mathrm{C} 66-\mathrm{C} 61-\mathrm{H} 61$ & 119.9 \\
\hline $\mathrm{C} 14-\mathrm{C} 13-\mathrm{H} 13$ & 119.9 & $\mathrm{C} 61-\mathrm{C} 62-\mathrm{H} 62$ & 119.9 \\
\hline $\mathrm{C} 14-\mathrm{C} 13-\mathrm{C} 18$ & $120.22(11)$ & $\mathrm{C} 63-\mathrm{C} 62-\mathrm{C} 61$ & $120.12(14)$ \\
\hline $\mathrm{C} 18-\mathrm{C} 13-\mathrm{H} 13$ & 119.9 & C63-C62-H62 & 119.9 \\
\hline $\mathrm{C} 13-\mathrm{C} 14-\mathrm{H} 14$ & 120.2 & $\mathrm{C} 62-\mathrm{C} 63-\mathrm{H} 63$ & 120.0 \\
\hline $\mathrm{C} 13-\mathrm{C} 14-\mathrm{C} 15$ & $119.66(12)$ & C64-C63-C62 & $120.07(13)$ \\
\hline
\end{tabular}




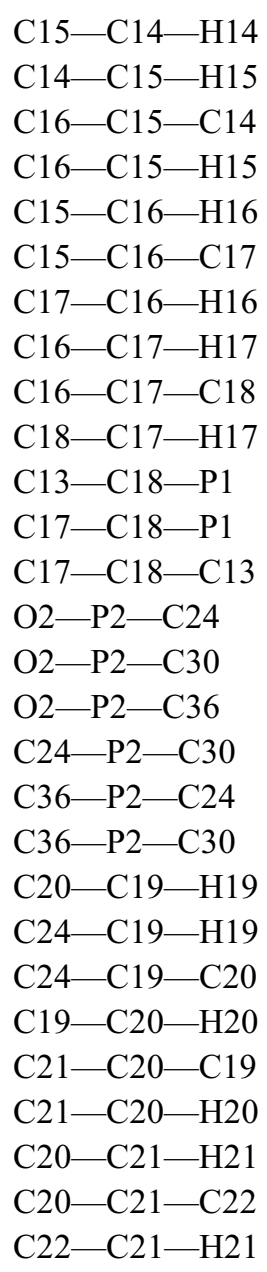

120.2

119.8

$120.38(12)$

119.8

119.9

$120.22(12)$

119.9

120.1

$119.82(11)$

120.1

$121.99(9)$

118.34 (9)

$119.66(11)$

$113.00(5)$

$110.92(5)$

$111.25(5)$

106.18 (5)

$107.09(5)$

$108.12(5)$

120.0

120.0

120.09 (11)

120.1

$119.78(11)$

120.1

119.8

120.45 (11)

119.8
C64- 63 - H63

C63-C64-H64

C63-C64-C65

C65-C64-H64

C64-C65-H65

C64-C65-C66

C66-C65-H65

C61-C66-P4

C61-C66-C65

C65-C66-P4

C68-C67-H67

C68-C67-C72

$\mathrm{C} 72-\mathrm{C} 67-\mathrm{H} 67$

C67- $668-\mathrm{H} 68$

C69-C68-C67

C69-C68-H68

C68-C69-H69

C68-C69-C70

C70-C69-H69

$\mathrm{C} 69-\mathrm{C} 70-\mathrm{H} 70$

$\mathrm{C} 69-\mathrm{C} 70-\mathrm{C} 71$

C71-C70-H70

$\mathrm{C} 70-\mathrm{C} 71-\mathrm{H} 71$

$\mathrm{C} 70-\mathrm{C} 71-\mathrm{C} 72$

$\mathrm{C} 72-\mathrm{C} 71-\mathrm{H} 71$

$\mathrm{C} 67-\mathrm{C} 72-\mathrm{P} 4$

C67-C72-C71

$\mathrm{C} 71-\mathrm{C} 72-\mathrm{P} 4$
120.0

119.9

120.19 (13)

119.9

119.9

120.23 (14)

119.9

$117.83(10)$

$119.14(12)$

$122.83(10)$

120.0

120.06 (12)

120.0

120.0

119.93 (12)

120.0

119.8

120.30 (12)

119.8

119.9

$120.30(12)$

119.9

120.2

$119.70(12)$

120.2

$121.96(10)$

$119.70(11)$

$118.33(9)$

Hydrogen-bond geometry $\left(A,{ }^{\circ}\right)$

\begin{tabular}{|c|c|c|c|c|}
\hline$D-\mathrm{H} \cdots A$ & $D-\mathrm{H}$ & $\mathrm{H} \cdots A$ & $D \cdots A$ & $D-\mathrm{H} \cdots A$ \\
\hline $\mathrm{O} 6-\mathrm{H} 6 \mathrm{O}^{\cdots} \mathrm{O} 4$ & $0.95(2)$ & $1.66(2)$ & $2.6070(12)$ & $171(2)$ \\
\hline $\mathrm{O} 8-\mathrm{H} 80 \cdots \mathrm{O} 1^{\mathrm{i}}$ & $0.90(2)$ & $1.70(2)$ & $2.5763(12)$ & $163(2)$ \\
\hline $\mathrm{O} 10-\mathrm{H} 10 O \cdots \mathrm{O} 2^{\mathrm{ii}}$ & $0.91(2)$ & $1.72(2)$ & $2.6077(12)$ & $163(2)$ \\
\hline $\mathrm{O} 12-\mathrm{H} 12 O \cdots \mathrm{O} 3^{\mathrm{iii}}$ & $0.90(2)$ & $1.71(2)$ & $2.5978(12)$ & $170.9(19)$ \\
\hline $\mathrm{C} 16-\mathrm{H} 16 \cdots \mathrm{O} 4$ & 0.93 & 2.53 & $3.3333(15)$ & 144 \\
\hline $\mathrm{C} 44-\mathrm{H} 44 \cdots \mathrm{O} 4^{\mathrm{iv}}$ & 0.93 & 2.43 & $3.2404(17)$ & 145 \\
\hline $\mathrm{C} 52-\mathrm{H} 52 \cdots \mathrm{O} 11^{\mathrm{v}}$ & 0.93 & 2.49 & $3.3231(16)$ & 149 \\
\hline $\mathrm{C} 62-\mathrm{H} 62 \cdots \mathrm{O} 11^{\mathrm{i}}$ & 0.93 & 2.51 & $3.367(2)$ & 153 \\
\hline $\mathrm{C} 64-\mathrm{H} 64 \cdots \mathrm{O} 5^{\mathrm{vi}}$ & 0.93 & 2.46 & $3.263(2)$ & 144 \\
\hline $\mathrm{C} 68-\mathrm{H} 68 \cdots \mathrm{O}^{\mathrm{vi}}$ & 0.93 & 2.55 & $3.2747(17)$ & 135 \\
\hline $\mathrm{C} 71-\mathrm{H} 71 \cdots \mathrm{O} 5$ & 0.93 & 2.59 & $3.2765(18)$ & 131 \\
\hline $\mathrm{C} 75-\mathrm{H} 75 \cdots \mathrm{O} 2^{\mathrm{i}}$ & 0.93 & 2.41 & $3.1184(16)$ & 133 \\
\hline $\mathrm{C} 96-\mathrm{H} 96 \cdots \mathrm{O} 1$ & 0.93 & 2.49 & $3.1832(15)$ & 132 \\
\hline
\end{tabular}

Symmetry codes: (i) $x+1, y, z$; (ii) $x+1, y, z+1$; (iii) $x, y, z+1$; (iv) $x-1,-y+1 / 2, z-3 / 2$; (v) $x,-y+1 / 2, z-3 / 2$; (vi) $x,-y+1 / 2, z-1 / 2$. 